\title{
Petroleum Business Strategies for Maintaining Positive Cash Flow and Corporate Liquidity Under Volatile Oil and Gas Prices as the Sustainable Energy Transition Unfolds
}

\author{
Maria do Socorro Cirilo Agostinho, ${ }^{1,2}$, Ruud Weijermars ${ }^{1, *}$ \\ ${ }^{1}$ Harold Vance Department of Petroleum Engineering, Texas A\&M University, TAMU College Station, Texas, USA \\ ${ }^{2}$ Department of Environmental and Technological Sciences, Federal Rural University of the Semiarid Region-UFERSA, Mossoro, Rio \\ Grande do Norte, Brazil
}

Email address:

R.Weijermars@TAMU.edu (R. Weijermars)

${ }^{*}$ Corresponding author

To cite this article:

Maria do Socorro Cirilo Agostinho, Ruud Weijermars. Petroleum Business Strategies for Maintaining Positive Cash Flow and Corporate Liquidity Under Volatile Oil and Gas Prices as the Sustainable Energy Transition Unfolds. Journal of Finance and Accounting. Vol. 5, No. 1, 2017, pp. 34-55. doi: 10.11648/j.jfa.20170501.14

Received: November 5, 2016; Accepted: December 1, 2016; Published: February 10, 2017

\begin{abstract}
To determine how the financing strategies and tactics of petroleum companies are affected by volatile market conditions, a cash-flow analysis was conducted of 30 oil companies with market capitalization ranging from USD 95 million (juniors) to USD 360 billion (majors). Our focus is on two critical recovery periods: 2004-2008 and 2009-2014. These intervals of market recovery are separated by the Great Recession of 2008-2009. The companies are divided into six traditional peer groups, classified by market capitalization and credit rating: oil majors, public private partnerships (PPP oils), independents, unconventionals, small caps, and juniors. Our analysis indicates that a high impact commodity price shock such as occurred during the global recession of 2008/2009 is more damaging to smaller companies than to bigger companies. However, post-recession data indicates that several of these smaller companies were able to recover and modify their practices to better protect themselves against future recessions. Smaller companies reduced dependence on external financing (from 35\% to $15 \%$ ), and of 16 companies in the "smaller" classification, 5 completely eliminated the need for long-term borrowing due to significant improvement in retained earnings. Success factors identified in this study include balancing capital expenditure with cash flow from operations, diversifying investments, divestiture of some assets, and focused efforts to reduce cash operating costs.
\end{abstract}

Keywords: Cash Flow Analysis, Oil And Gas Companies, Capital Expenditure, Operating Income, Financing Activities, Uncertain Market

\section{Introduction}

At present, the global energy system is led by market dynamics that motivate business decisions to privatize profits and socialize the cost of pollution and GHG emissions rather than being guided by total energy optimization criteria (see Energy Strategy Research Charter; [1]). A holistic framework that optimizes decision-making at every step in the global energy system would be desirable [2], but is currently not in place. Although the scientific community recognizes the need to transition from fossil fuels to renewable energy solutions, global energy demand still grows, due to which all energy supply systems continue to grow in absolute terms [2]. Consequently, the market share of crude oil commonly is little affected by fuel switches and the effect of climate policies on fossil fuel consumption patterns has remained negligible [3]. Today, fossil fuels still comprise a major market share in the global energy system: oil and gas jointly make up for $58 \%$ of 2015 primary energy demand [4]. The slow transition has climate change consequences and impacts the commons [5], which will have costly repercussions for future generations.

As long as the transition to sustainable energy unfolds 
and emission tax penalties are not globally applied in current energy policies, oil and gas resources remain primary energy sources fundamental to the worldwide economy [6]. Discovering new oil and gas reserves is essential to buy time to develop affordable energy alternatives to replace fossil fuels. Although fossil fuels have traditionally relatively low marginal cost of supply, the required reserves replacement over the past decade has become more capital intensive than before $[7,8]$. To meet the mounting capital requirements for reserves replacement, oil and gas companies continue to strive for sufficient free cash flow generated from current income and thus try to prevent life-cycle decline of current assets in order to avert any decline of future cash flows [9, 10]. Without investment in exploration to find new reserves to replace oil and gas production, the petroleum industry would vanish $[11,12]$. However, when oil and gas prices decline due to either weak demand or overproduction, or both, companies cannot but delay exploration in order to avert negative cash flow or to mitigate cash accounts that are already negative from going further in the red. A balanced investment strategy must ensure that capital for exploration and production of new fields can either be earned from operations or raised from investors [13].

Importantly, when the business environment for oil and gas companies deteriorates, not all companies are equally affected. A previous analysis of corporate cash flow metrics, covering the pre-recessional period of 2004-2008, revealed that the operational income of smaller oil and gas companies was often insufficient to fund capital expenditure (CAPEX) for new projects [14]. The dependence on external financing was greatest for juniors and least for the oil majors for the 5-year period before the great recession of 2008-2009. Smaller oil companies (USD 0.5 billion to USD 50 billion market capitalization) typically depend on external financing to cover new project CAPEX because they cannot generate sufficient net cash from operations. In contrast, the oil majors, public-private partnerships (PPP) and independents can normally fully fund new project CAPEX exclusively with net cash from operating activities [14]. Cash surpluses are invested in financing activities, i.e., paying dividends, buying back common shares, and retiring or refinancing debt.

The objective of the present study is to expand the previous analysis of corporate cash flows across the 2008/2009 epoch of deteriorating oil and gas prices. Our study uses the cash flow statements of 30 oil companies, applying the same methodology used in the earlier cash flow assessment [14]. The peer groups selected for our present study cover six categories of companies, primarily classified according to their market capitalization and credit rating (Table 1 and Figure 1): juniors, small caps, unconventionals, independents, PPP oils, and oil majors. To ensure continuity of time-series, the present study first reexamines the results of the earlier study [14] and then expands the cash flow analysis using 11 year time-series to cover the financial performance of the peer group companies across the two recovery periods 2004-2008 and 2009-2014, and into the low oil price regime of 2014/2016.

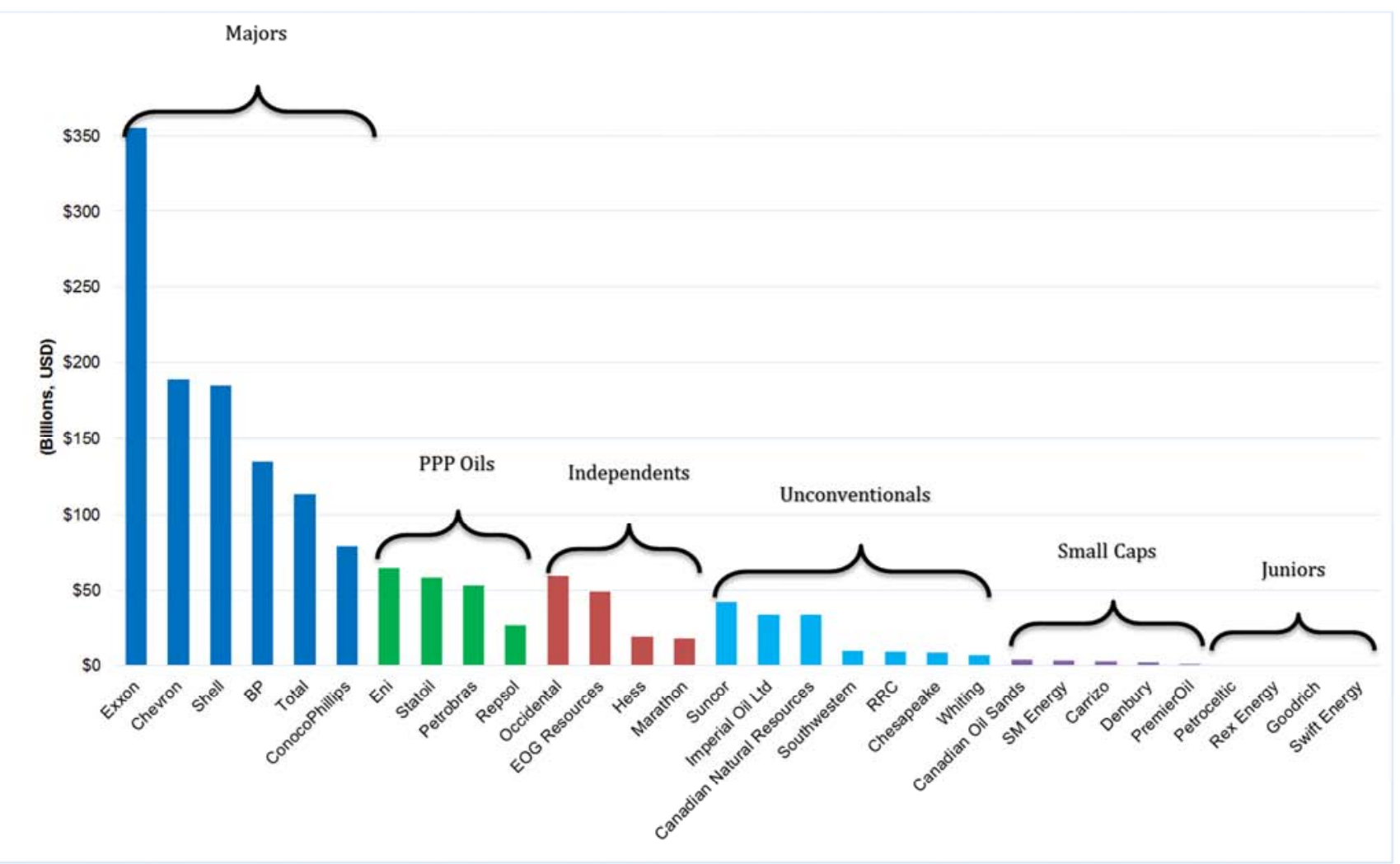

Figure 1. Market capitalization (June 2015) of the companies studied and their respective peer groups. 
Table 1. Capitalization categories and panel of peer groups studied.

\begin{tabular}{|c|c|c|c|c|c|}
\hline \multicolumn{6}{|c|}{ Capitalization (billions, USD) } \\
\hline $0.5<$ & & & $0.5-5$ & & \\
\hline \multicolumn{6}{|c|}{ Smaller companies } \\
\hline \multicolumn{2}{|c|}{ Juniors } & \multicolumn{2}{|c|}{ Small Caps } & \multicolumn{2}{|c|}{ Unconventionals } \\
\hline $\begin{array}{l}\text { American } \\
\text { Rex Energy } \\
\text { Goodrich } \\
\text { Swift Energy }\end{array}$ & $\begin{array}{l}\text { European } \\
\text { Petroceltic }\end{array}$ & $\begin{array}{l}\text { American } \\
\text { SM Energy } \\
\text { Carrizo } \\
\text { Denbury }\end{array}$ & $\begin{array}{l}\text { European } \\
\text { PremierOil }\end{array}$ & $\begin{array}{l}\text { Canadian Oil } \\
\text { Canadian Oil Sands }\end{array}$ & $\begin{array}{l}\text { American } \\
\text { Southwestern } \\
\text { Range Resources } \\
\text { Chesapeake } \\
\text { Whiting }\end{array}$ \\
\hline
\end{tabular}

Table 1. Continued.

\begin{tabular}{|c|c|c|c|c|c|}
\hline \multicolumn{6}{|l|}{ Capitalization (billions, USD) } \\
\hline $5-50$ & & & $>\mathbf{5 0}$ & & \\
\hline \multicolumn{6}{|l|}{ Bigger companies } \\
\hline \multicolumn{2}{|c|}{ Independents } & \multicolumn{2}{|c|}{ PPP Oils } & \multicolumn{2}{|c|}{ Majors } \\
\hline $\begin{array}{l}\text { Canadian } \\
\text { Suncor } \\
\text { Imperial } \\
\text { Canadian Natural Resources }\end{array}$ & $\begin{array}{l}\text { American } \\
\text { Occidental } \\
\text { EOG Resources } \\
\text { Hess } \\
\text { Marathon Oil }\end{array}$ & $\begin{array}{l}\text { Brazilian } \\
\text { Petrobras }\end{array}$ & $\begin{array}{l}\text { European } \\
\text { Eni } \\
\text { Statoil } \\
\text { Repsol }\end{array}$ & $\begin{array}{l}\text { American } \\
\text { Exxon } \\
\text { Chevron } \\
\text { Conoco Phillips }\end{array}$ & $\begin{array}{l}\text { European } \\
\text { Shell } \\
\text { BP } \\
\text { Total }\end{array}$ \\
\hline
\end{tabular}

Our study is significant because it shows how the assets of different classes of oil and gas companies are financed and how each class of companies adjusts through periods of recovery following downturns. For companies to maintain liquidity during longer epochs of depressed commodity prices, such as occurred during the financial crisis of 2008/2009 and the most recent decline of 2014/2016 related to the Saudi-US oil price war (a term coined in a companion study by Rodrigues and Weijermars [15]), they must adequately manage the effects of lower operational income due to the adverse market conditions. The efficacy of any strategic response to adverse market conditions will differentiate the winners from the losers in the global competition for energy market shares. Our study provides a summary of the different strategies that have been used by petroleum companies to rebound from recessional market conditions and how these strategies have impacted improvement of cash flow. Some important insights can be gleaned from our study to guide companies toward a recovery strategy from the recent downturn in commodity prices.

This study is organized as follows. First, we outline a conceptual enterprise model (Section 2.1) and the applied methodology for our cash flow analysis (Section 2.2), followed by a brief executive summary of the principal results (Section 2.3). Next, the results of our cash flow analysis are detailed by systematically discussing each peer group's performance and of individual companies (Section 3). The rising trend in CAPEX and lagging cash flow growth are highlighted in Section 4. After a brief discussion (Section 5), this study ends with conclusions (Section 6).

\section{Enterprise Models, Cash Flow Analysis and Summary Results}

Two conceptual enterprise models are first introduced below based on the findings of the earlier cash flow analysis
$[14,16]$, followed by a brief outline of the cash flow analysis methodology itself and an executive summary of the main results. Details are subsequently elaborated later in this article.

\subsection{Conceptual Enterprise Models}

From an investor point of view, the enterprise is a cash flow machine with detailed value drivers and valuation components that are affected by management decisions, which ultimately must generate positive shareholder returns [17]. The cash flow statement is one of the three main corporate financial reporting statements that describe the operating and financial accounts of the company [18]. Cash payments (uses of cash) and receipts (sources of cash) move between operating, investing, and financing activities. Sources of cash can be distinguished in internal, external, hybrid, and other, as follows:

A. Internal source of cash: Operational income

- Retained earnings (retained profits from operations)

B. External sources of cash: Financing activities

- Long-term and short-term debt

- New share capital or equity

C. Hybrid source of cash: Investment activities

- Asset Sales (internal, current assets divested to raise external cash)

D. Other instruments

- Volumetric production payments

- Contract financing

- Government grants

- Tax credits

A strong and consistent cash flow primarily based on internal sources of cash is desired by any company that wants to become or continue being successful. Positive cash flow enables companies to develop new projects, add retained earnings to the balance sheets, increase dividends, pay debts, buy back shares, and attract investors [19]. Cash flow from operations should be large enough to finance growth and 
reduce the cost of capital, which is a challenge for growth companies as compared to mature companies [20], as is succinctly explained below. We consider two principal types of companies: Mature companies and young growth companies, each of which merits a brief discussion because their cash flow generating capacities are markedly different.

\section{A) Mature Companies}

An earlier cash flow analysis over the 5-year period (20042008) showed that the bigger, mature oil companies (oil majors, PPP oils and independents) on average used $70 \%$ of net income (mostly from operations) to finance growth through investing activities and $30 \%$ of net income was paid as dividends to shareholders $[14,16]$. The explanation for the historic reliance of mature companies on cash from operations is explained by a conceptual enterprise model for mature companies, as follows.

A mature company finances business growth mostly by retained earnings from operational income occasionally supplemented by the proceeds of asset sales. Such asset sales do not change the total asset value on the balance sheet, because the sold, real asset's value is commonly monetized into a current asset with corresponding fair value on the cash

a)

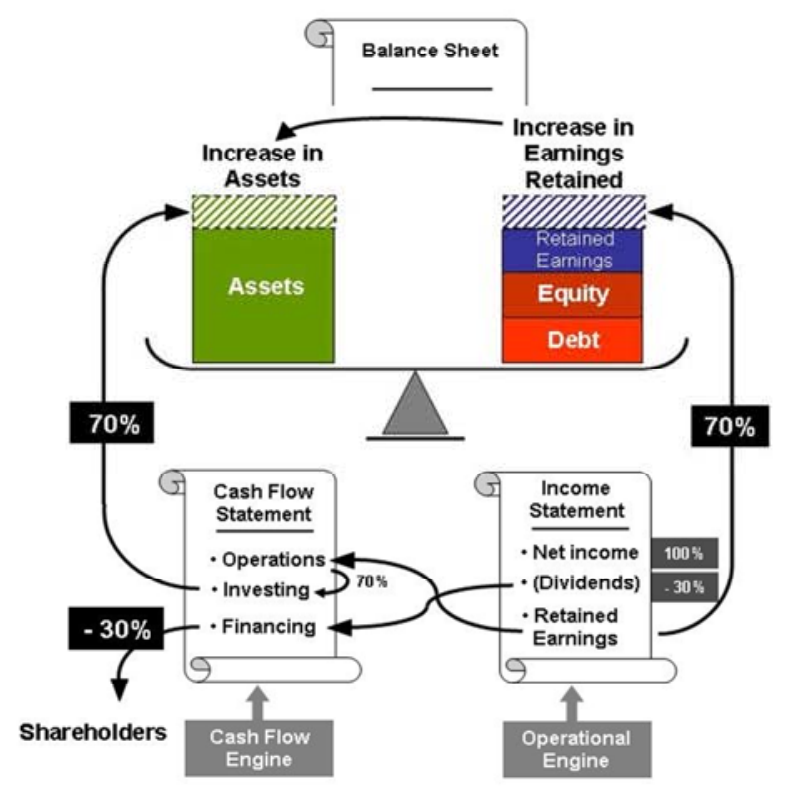

account (Figure 2a). Assuming the balance sheet holds both cost information (depletion, depreciation, and amortizationDD\&A) and capitalization of recognized reserves, we conclude asset sales more often than not will not significantly alter the balance sheet, unless companies are distressed and forced to sell or swap assets below market value. Consequently, the main source of cash in any mature company is earnings retained from operations as recorded on the income statement, which transfers to cash from operations on the cash flow statement. Cash retained from operations (so-called retained earnings) are equal to after tax earnings (profits) minus dividends (or cost of any share buybacks). Dividends withheld from the operational income appear as (negative, cash outflow) entries under financing activities on the cash flow statement. Fundamental owner's equity in the company recorded on the balance sheet mostly grows by the increase in retained earnings (= net incomedividends). It should be noted that retained earnings reported on the balance sheet are cumulative since the incorporation of the company, whereas those on the income and cash flow statements are annualized results.

\section{b) Young growth company}

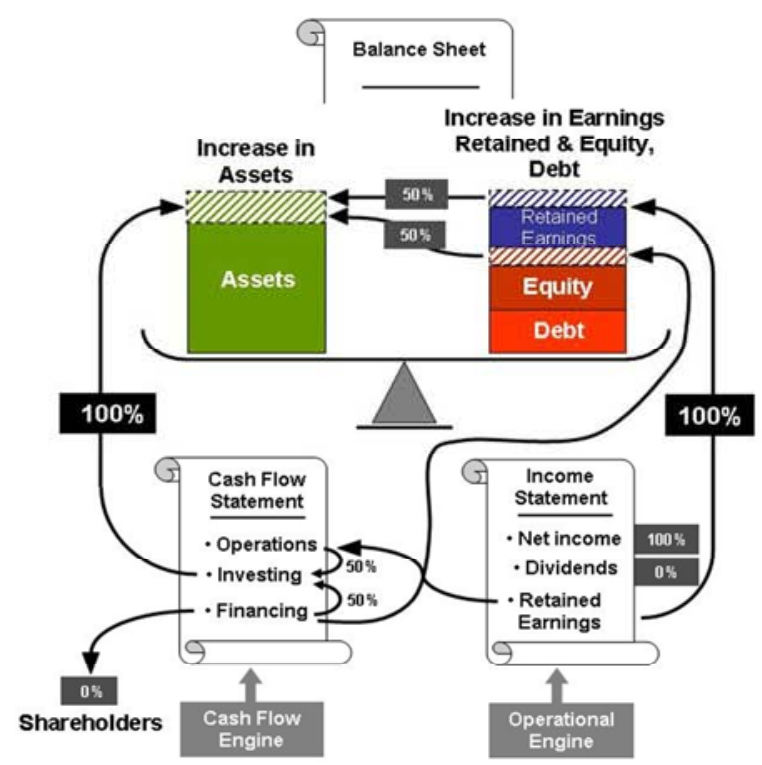

Figure 2. (a): Mature firms can finance further asset growth with retained earnings from operations. Operational income is large enough to award dividends to shareholders (or share buybacks) and still leaves enough retained earnings to finance all future asset growth. (b): Young growth firms do not award dividends and reinvest all net income (=retained earnings when no dividends are subtracted) in further asset growth. However, the operational earnings commonly are insufficient to finance growth and, in our above example, meet only half of the capital investment requirement. Supplementary income from financing activities is required to pay for the other half of the new capital investments.

Share buy-backs in lieu of paying dividends may directly transfer to a theoretical capital gain for the residual shareholders, and may or may not provide monetized capital gains for the selling shareholders. Buying shares reduces supply and therefore will likely lead to an increase of the price of the company shares. In mature firms, shares commonly remain undiluted in the absence of the firm drawing any substantial income from financing activities. Capital gains related to the firm's share price are substantially supported by real asset growth, which is fully financed by positive growth in retained earnings (Figure 2a). Total shareholder returns (TSR) are made up of capital gains plus dividend payments [21].

\section{B) Young Growth Companies}

The earlier cash flow analysis $[15,16]$ showed that smaller oil companies (juniors, small caps and unconventional oil producers) on average were forced to raise half of the capital needed to finance growth from financing activities because 
net income from operations would fall $50 \%$ short of the sum required to finance growth. The explanation for the historic dependency of growth companies on external financing is explained by a conceptual enterprise model for young growth companies, as follows.

In a young growth company asset growth is mainly financed by raising large sums of long-term debt (debt capital) and issuing new shares (equity capital), less so by retained earnings (Figure 2b). Owner's equity will not increase much for such companies because share value does not benefit from new equity capital or debt growth, both of which only result in a corresponding cash account increase. For owner's equity to grow in a manner that benefits each shareholder (real value creation) the balance sheet needs to show growth of retained earnings. However, asset growth in young firms is commonly financed only in part by retained earnings (Figure 2b). Additional capital for growth needs to be continually raised from debt financing and/or new equity issuance, neither of which creates residual asset value growth for the existing shareholders, as can be explained as follows. New share issuance leads to share dilution proportional to the raised equity finance. New debt acquisition leads to an increase in liabilities corresponding to the portion of new assets financed by the debt. As no dividends are awarded by the growth company, capital gain (or loss) is the sole source of gain (or loss) for shareholders so TSR equals capital gains.
In such cases, much of the capital gain is speculative rather than underpinned by growth in debt-free asset value [21].

\subsection{Cash Flow Analysis Methodology}

In our study, all data for the six peer groups studied (Figure 1, Table 1) is abstracted from client reports of credit rating agencies, annual and quarterly SEC-filings, and annual reports of the companies selected for our study. In order to be able to compare all cash-flow statements regardless of the absolute amount involved, the collected data were normalized using the algorithms given in Table 2. The algorithms to be used were determined by an "if" statement that checks whether cash flow from operations (CFO) is either larger or smaller than the capital expenditure $[\mathrm{CFO}>|\mathrm{CAPEX}|$ or $\mathrm{CFO}<|\mathrm{CAPEX}|]$, after which a specific set of algorithms can be applied to normalize the principal cash flows (Table 2). The algorithms capture the contribution of the two main sources of funds for any company, which are (1) net cash from operations and (2) net cash from financing activities. If the operational income is insufficient to fund new projects, additional funds need to be raised from financing activities [14], and time-series of the relative contribution for each peer group and its individual companies follow from our analysis below.

Table 2. Principal algorithms used to normalize cash-flow statements. In the analyses the algorithms (left or right columns) were determined by an "if" statement that checks whether $C F O>|C A P E X|$.

\begin{tabular}{|c|c|c|}
\hline \multirow{2}{*}{ Cash Flow Components } & \multicolumn{2}{|c|}{ ALGORITHMS USED TO NORMALIZE CASH FLOW STATEMENTS. } \\
\hline & IF CFO > $\mid$ CAPEX $\mid$ & IF CFO $<\mid$ CAPEX $\mid$ \\
\hline Capital Expenditure & $(C A P E X)=\frac{C A P E X}{(C F O+E X-S U R P L U S)}$ & $(C A P E X)=\frac{C A P E X}{(C F O+F I N A N+E X-S U R P L U S)}$ \\
\hline Net income from operations & $(C F O)=\frac{C F O}{(C F O+E X-S U R P L U S)}$ & $(C F O)=\frac{C F O}{(C F O+F I N A N+E X-S U R P L U S)}$ \\
\hline $\begin{array}{l}\text { Net income from financing } \\
\text { activities }\end{array}$ & $(F I N A N)=\frac{F I N A N}{(C F O+E X-S U R P L U S)}$ & $(F I N A N)=\frac{F I N A N}{(C F O+F I N A N+E X-S U R P L U S)}$ \\
\hline $\begin{array}{l}\text { Currency Exchange rate } \\
\text { correction }\end{array}$ & $(E X)=\frac{E X}{(C F O+E X-S U R P L U S)}$ & $(E X)=\frac{E X}{(C F O+F I N A N+E X-S U R P L U S)}$ \\
\hline Cash surplus/ deficit for the year & $(S U R P L U S)=\frac{S U R P L U S}{(C F O+E X-S U R P L U S)}$ & $(S U R P L U S)=\frac{\text { SURPLUS }}{(C F O+F I N A N+E X-S U R P L U S)}$ \\
\hline
\end{tabular}

Credit rating data were used to support our selection of peer groups as is specified in Table 3 . The credit rating scale has an opposite correlation with the risk of non-payment of debt. Credit rating changes can have a substantial effect on the financial markets and may have a profound influence on interest rates charged by banks. Credit rating agencies normally assign grades corresponding to creditworthiness of the companies $[22,23]$. A brief analysis of the impact of the oil and gas price declines (via the cash flow declines) over the past decade on the credit ratings of all companies in our study is given in the discussion section of this paper (Section 5.2).

Table 3. Generic schedule for corporate growth and credit-rating grade.

\begin{tabular}{|c|c|c|c|}
\hline \multirow{2}{*}{ Market Capitalization } & \multirow{2}{*}{ Capitalization Range } & \multirow{2}{*}{ Production } & Corresponding Credit \\
\hline & & & Rating Inventory \\
\hline Large-cap & $\$ 50-\$ 500$ billion & $100,000+$ bpd & $\mathrm{AAA}, \mathrm{AA}+, \mathrm{AA}, \mathrm{AA}-, \mathrm{BBB}+$ \\
\hline Med-cap & $\$ 5-\$ 50$ billion & $10,000-100,000 \mathrm{bpd}$ & AA-, BBB+, BBB-, BB \\
\hline Small-cap & $\$ 500$ million to $\$ 5$ billion & $500-10,000 \mathrm{bpd}$ & BB-, B+, B, B- \\
\hline Micro-cap & under $\$ 500$ million & $>500 \mathrm{bpd}$ & Non-rated, B or lower \\
\hline
\end{tabular}

Source: Society of Petroleum Engineers 


\subsection{Executive Summary of Cash Flow Analysis}

Each peer group was subjected to an in-depth cash flow analysis, the results of which are detailed later in this paper. A brief overview of our results is given below, highlighting some important main trends. After reexamining the first performance period (2004-2008), our results confirm the earlier finding $[14,16]$ that the bigger companies can fully fund the CAPEX of new projects using operating cash flow and can also spend their excess earnings on financing activities. After fully covering the CAPEX of new projects, bigger companies still had $34 \%$ of net cash from operations available to spend on financing activities (Figure 3a).

The present study classifies oil majors, independents, and PPP oils as "bigger" oil companies (14 companies). The earlier study had a similar break down using 13 companies [14]. All companies listed in Table 1 for majors, PPP oils, and independents are identical to those used in Weijermars (2011), except for EOG Resources, which was not included in that earlier study. The present numbers of $71 \%$ of operational cash flow assigned to investing activities and $27 \%$ to financing activities (Figure 3a) are similar to the earlier numbers of $69 \%$ and $31 \%$, given in Weijermars (2011) for the same study period (2004-2008). The latter numbers were used for the generic breakdown of cash sources and sinks of the typical mature company portrayed in Figure 2a. The present study expanded the cash flow analysis to include the 6-year period (2009-2014) after the great recession (Figure 3b). We see that the bigger companies began spending a larger percentage of their net cash from operating activities on new projects, which has eroded their ability to spend excess earnings on financing activities, from $34 \%$ to $30 \%$ (Figure $3 b$ ).

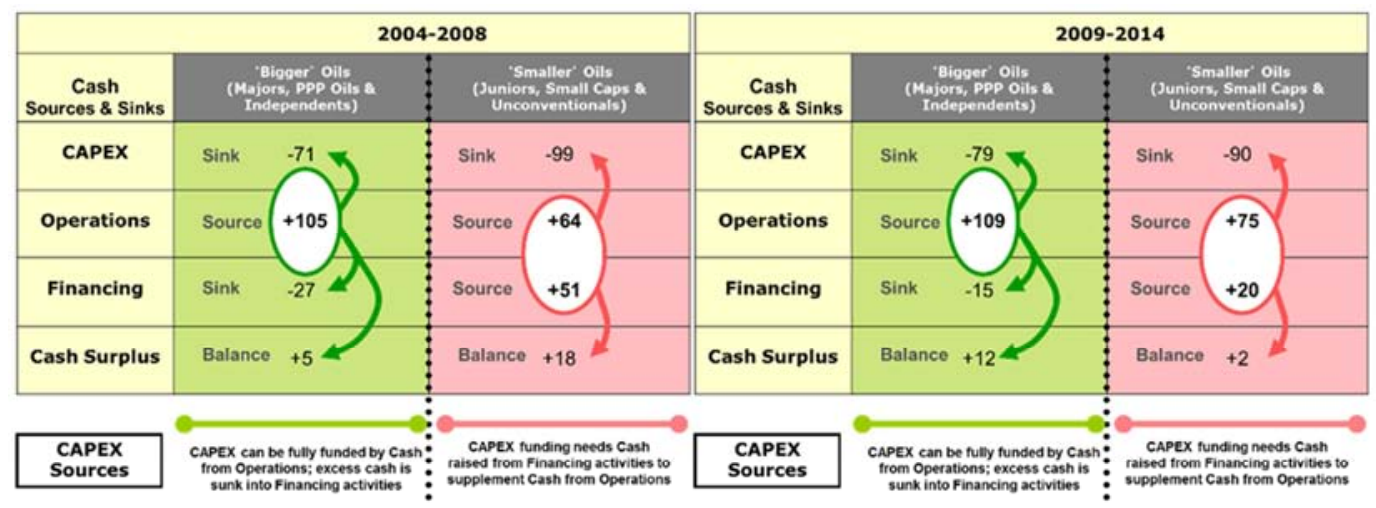

3 a)

3 b)

Figure 3. (a)-Cash-flow numbers show the percentage of annualized cash-flow sources (+) and sinks (-) on the basis of 5-year averages (2004-2008). A clear contrast exists between the cash sources of smaller companies and those of bigger companies (see Table 1 for grouping). Smaller companies supplement operational cash with external financing. (b)-Cash-flow numbers of 6-year averages (2009-2014). Bigger oil companies started spending a larger percentage of operational earnings on CAPEX on new projects and reduced their cash flow to financing activities from 27\% (in 2004-2008) to 15\% (in 2009-2014). Smaller oil companies were able to reduce significantly the dependence on external financing from $35 \%$ to $15 \%$.

Our analysis of the smaller companies includes unconventionals, small caps and juniors (Table 1), comprising 16 companies. The earlier study [14] only used 11 companies, several of which have since gone bankrupt or have been bought by other entities. Only seven companies of the present pool (Rex, Petroceltic, Premier, Chesapeake, Whiting, and Suncor) were used in the previous sample group of smaller companies. In spite of the partial difference in the sample group we find for the first period (2004-2008), a similar result in that smaller companies are unable to generate sufficient net cash from operations to cover CAPEX of new projects, being dependent on external financing. During 2004-2008, the average result showed that smaller companies funded $35 \%$ of their CAPEX for new projects from external financing. This new result confirms the general finding of the previous study [14], which found smaller companies to cover $50 \%$ of investments from operational cash flow and $50 \%$ from financing activities (Figure 2b). The difference in percentage can be ascribed to the different sample groups used. However, through the second period studied (2009-2014), smaller companies performed much better as compared to the first period (2004-2008). The external financing dependency continues to exist in the second period, but the need for external financing fell sharply from 35 to $15 \%$. This improvement is due to a significant increase in net cash from operating activities from $64 \%$ in the first period to $75 \%$ in the second period.

Looking at the six peer groups separately (Figure 4a and Figure $4 b$ ), the unconventional peer group draws attention. In the first period (2004-2008), the average result revealed that the unconventional oil companies (U.S. shale producers and Canadian oil sands producers) funded $15 \%$ of their CAPEX for new projects from external financing (Figure 4a). However, in the second period (2009-2014), the unconventionals showed an extraordinary improvement, managing to cover CAPEX of new projects fully with cash from operating activities (Figure 4b). In essence, the unconventionals crossed the division and mirrored the operational cash flow engine of bigger oil companies. The principal results of our detailed cash flow analysis on the peer group level are stepwise discussed in the next section. 


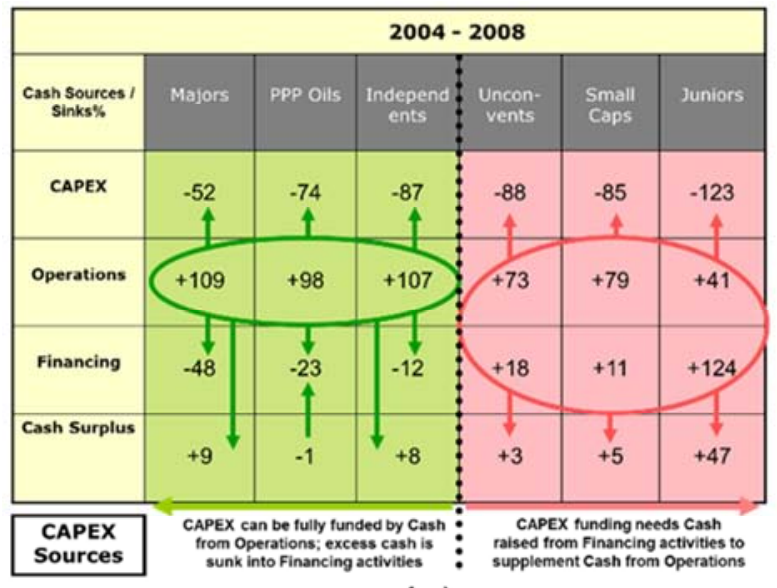

4 a)

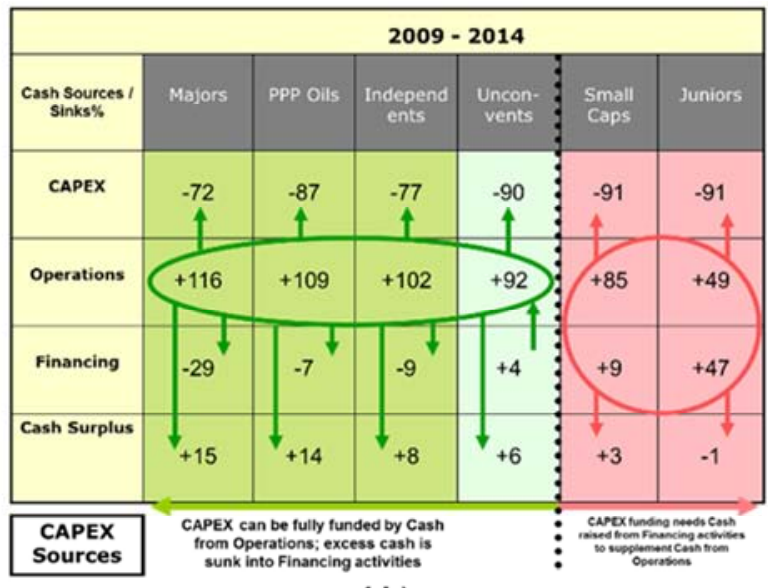

4 b)

Figure 4. (a)-Cash flow break down for each peer groups. The numbers show the percentage of annualized cash-flow sources (+) and sinks (-) on the basis of 5-year averages (2004-2008). Oil majors can fully fund CAPEX of new projects from operational cash. Technically, PPP oils and independents can also fund CAPEX projects without external financing. Conversely, unconventional, small-caps and juniors oil companies funded 15\%, 6\%, and 82\%, respectively, of their CAPEX for projects from external financing. (b) Cash flow of 6-year averages (2009-2014) for each peer group. Oil majors, PPP oils, and independents still can fully fund CAPEX of new projects from operational cash. In principle, unconventional oil companies have been able to fund CAPEX projects without external financing. Small caps and juniors, even though succeeding increased cash from operating activities, still need to raise cash from external financing.

\section{Cash-Flow Analysis of Peer Groups}

\subsection{Major Oil and Gas Companies}

The oil major peer group consists of six companies (Table 1 and Figure 1): ExxonMobil, Chevron, ConocoPhillips, Shell, BP and Total. The first three are American companies and the last three are European companies. All major companies present a superior cash flow supported by their strong operational performance. Their integrated portfolios have helped them to keep profitable levels even with lower demand in times of economic downturn and volatile commodity prices.

A) First period (2004-2008). In this period, ExxonMobil showed the strongest cash flow performance of the majors peer group. Margins and turnover from operations provided exceptional cash flow, of which just $29 \%$ was needed to cover all CAPEX for new projects and a robust $71 \%$ was sunk into its financing activities. The numbers shown in Table $4 \mathrm{a}$ are the real averages for each company in the major peer group over the first 5-year period studied (2004-2008). During this first period the peer group average results shows that, after covering all new project CAPEX exclusively with cash from operating activities, $48 \%$ operational income was sunk into financing activities (retiring or refinancing debt, paying dividends and buying back common shares) with an annual cash account surplus of $9 \%$.

B) Second period (2009-2014). In the second period, all companies in this peer group (except ConocoPhillips), began using a larger amount of the net cash from operating activities for new project CAPEX. The larger cash requirement is attributed to the complexity of recently discovered hydrocarbon reserves, which are more costly to develop [7, 8]. The numbers presented in Table $4 \mathrm{~b}$ are the real averages from the major peer group over the 6-year period. After fully funding CAPEX of new projects from operational cash flow, companies in this peer group spent $29 \%$ of excess earnings on financing activities and had an annual cash account surplus of $15 \%$. However, increasing the amount allocated to investment activities was not necessarily reflected in an increase in operating income (Figure 5). For example, ExxonMobil had an annual average of USD 49.9 billion of net cash from operating activities in the first period (2004-2008) against USD 46.4 billion annual average in the second period (2009-2014), even though CAPEX for new projects increased from USD 12.9 billion to USD 25.9 billion annual average. Chevron presented better improvement in this peer group in the second period by increasing its annual average net cash from operating activities from USD 23.7 billion (in the first period) to USD 31.2 billion (in the second period).

Table 4a. Cash-flow sources (+) and sinks (-) for oil majors (5-year averages, 2004-2008).

\begin{tabular}{|c|c|c|c|c|c|c|c|}
\hline Percentage & Exxon & Chevron & Conoco & Shell & BP & Total & Mean \\
\hline CAPEX & -29 & -52 & -69 & -48 & -44 & -70 & -52 \\
\hline Operations & +112 & +111 & +97 & +111 & +104 & +118 & +109 \\
\hline Financing & -71 & -48 & -26 & -52 & -56 & -32 & -48 \\
\hline Exchange & 0 & 0 & 0 & 0 & 0 & -2 & 0 \\
\hline Cash surplus & +12 & +11 & +2 & +11 & +4 & +16 & +9 \\
\hline
\end{tabular}


Table 4b. Cash-flow sources (+) and sinks (-) for oil majors (6-year averages, 2009-2014).

\begin{tabular}{llllllll}
\hline Percentage & Exxon & Chevron & Conoco & Shell & BP & Total & Mean \\
\hline CAPEX & -51 & -82 & -43 & -77 & -83 & -93 & -72 \\
Operations & +91 & +104 & +115 & +106 & +167 & +112 & +116 \\
Financing & -49 & -20 & -58 & -24 & -16 & -9 & -29 \\
Exchange & 0 & 0 & 0 & -1 & -2 & -2 & -1 \\
Cash surplus & -9 & +2 & +15 & +4 & +65 & +10 & +15 \\
\hline
\end{tabular}

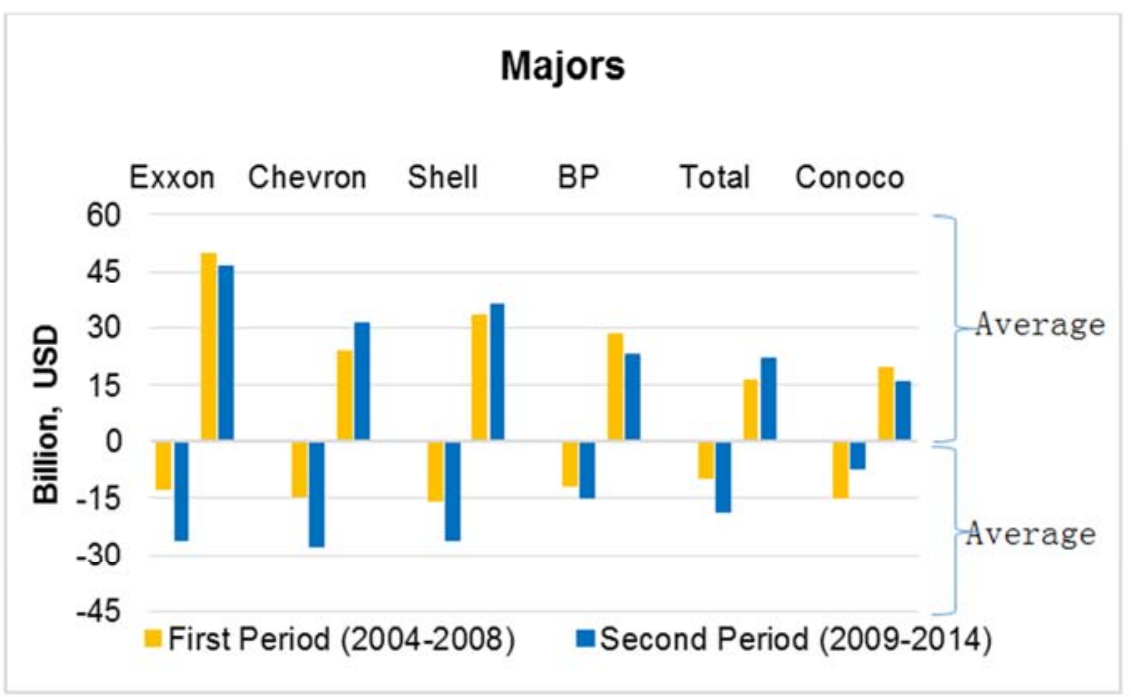

Figure 5. Majors: Average amount in USD billion of cash generated by operations (CFO) and cash spent on CAPEX for new projects. During the period up to the great recession (2004-2008) cash flow from operations by far exceeded capital expenditure on investing activities. During the second period (2009-2014) all companies, except ConocoPhillips, spent significantly on investing activities, while CFO did not grow to match the cost.

\subsection{PPP Oil and Gas Companies}

The four PPP oil companies (Table 1 and Figure 1), comprising three European companies (Eni, Statoil, and Repsol) and one Brazilian company (Petrobras), have strong operational performance. In principle, their main source of financing for investments is generated by operating cash flow. They also have integrated portfolios with expertise in both upstream and downstream business.

A) First period (2004-2008). The average results for this period show that PPP oil companies were able to fully fund CAPEX of new projects with cash generated from operating activities. Table 5a presents the real averages from the PPP oils peer group over the 5 -year period. After capitalizing all CAPEX of new projects entirely with cash from operating activities, $24 \%$ was sunk into financing activities. Eni and Repsol showed better results among the peer group: $65 \%$ and $68 \%$ of $\mathrm{CFO}$ respectively was necessary to cover all CAPEX projects, and $32 \%$ was sunk in financing activities for both companies.

B) Second period (2009-2014). The average results of this peer group over the 6-year period, even though they had shown the ability to cover CAPEX without external financing, indicate a decrease in their excess earnings from $23 \%$ to $7 \%$ (Table $5 b$ ).
After covering CAPEX for new projects and other investment activities, only $7 \%$ of CFO remained to be spent in financing activities. In this period, Petrobras had to rely heavily on external financing to supplement the cash from operating activities to cover all CAPEX projects. Petrobras and Statoil started to allocate more resources to investment activities (Figure 6); therefore, operational earnings were no longer siphoned into financing activities. Petrobras increased its annual average investments from USD 17.2 billion (in the first period) to USD 40 billion (in the second period). Statoil increased from NOK 57.5 billion (in the first period) to NOK 92.6 billion (in the second period). Both companies focused on onshore upstream activities. The opposite investment strategy was followed by Eni and Repsol, which reduced the average annual amount on investment from EUR 11.5 billion to EUR 10.5 billion and EUR 4.1 billion and EUR 2.7 billion in the first to the second period, respectively. However, Eni and Repsol saw their CFO decline in the second performance period (2009-2014) (Figure 6). Petrobras was able to increase the annual average net cash from operating activities from USD 19 billion to USD 28.4 billion, and for Statoil the growth was from NOK 76 billion to NOK 104.8 billion in the second period.

Table 5a. Cash-flow sources (+) and sinks (-) for PPP oils (5-year averages, 2004-2008).

\begin{tabular}{llllll}
\hline Percentage & Eni & Statoil & Petrobras & Repsol & Mean \\
\hline CAPEX & -65 & -77 & -85 & -68 & -74 \\
Operations & +99 & +102 & +98 & +94 & 98 \\
Financing & -32 & -12 & -15 & -32 & -23 \\
Exchange & 0 & 0 & +2 & -1 & 1 \\
Cash surplus & +2 & +2 & -3 & -6 & -1 \\
\hline
\end{tabular}


Table 5b. Cash-flow sources (+) and sinks (-) for PPP oils (6-year averages, 2009-2014).

\begin{tabular}{llllll}
\hline Percentage & Eni & Statoil & Petrobras & Repsol & Mean \\
\hline CAPEX & -89 & -92 & -100 & -69 & -87 \\
Operations & +114 & +103 & +73 & +144 & +109 \\
Financing & -11 & -1 & +32 & -49 & -7 \\
Exchange & 0 & 0 & -1 & 0 & 0 \\
Cash surplus & +14 & +10 & +5 & +26 & +14 \\
\hline
\end{tabular}

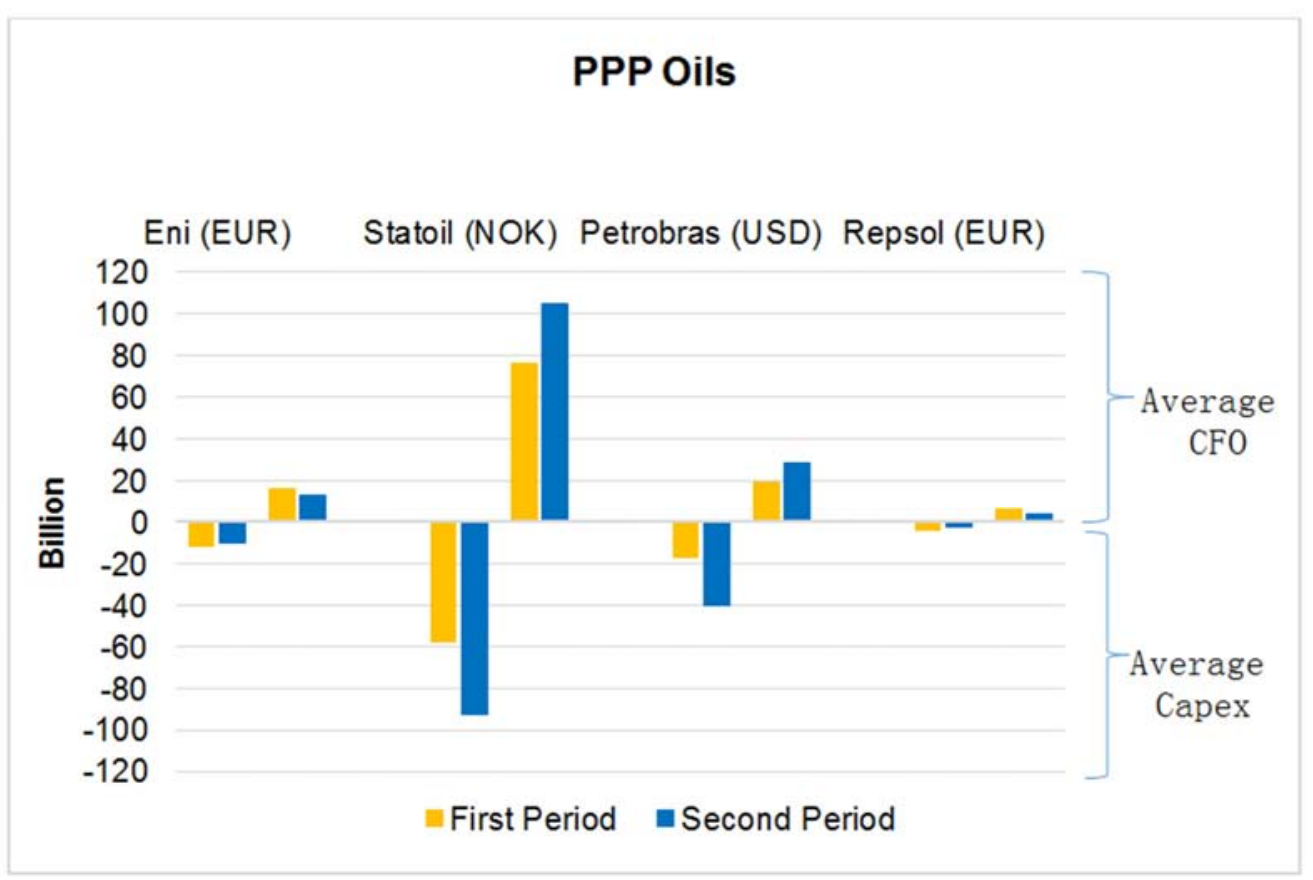

Figure 6. PPP oils: Average amount of cash generated by operations (CFO) and cash spent in CAPEX of new projects. The currency is specified for each company.

\subsection{Independent Oil and Gas Companies}

Four American companies make up this peer group (Table 1, Figure 1): Occidental, EOG Resources, Hess and Marathon Oil. All are considered successful companies that over the years have maintained a fairly consistent cash flow and strong operational performance. Three of them have over 95 years' experience in the oil and gas sector. EOG is the youngest among them and was founded in 1999.

A) First period (2004-2008). The normalized average results over the first 5 -year period of cash flow data are presented in Table 6a. The results showed $87 \%$ of CFO was sufficient to cover all CAPEX projects and 12\% from retained earnings was sunk into financing activities plus an annual cash account surplus of $8 \%$. Occidental had the best cash flow performance in this peer group, using only $69 \%$ of CFO to cover all CAPEX needs with $31 \%$ of excess earnings from operational income spent on financial activities.

B) Second period (2009-2014). The pattern of cash flow sources and sinks for the independents in the second period remained similar to the first period. The normalized average results over the 6-year period of cash flow performance are presented in Table $6 \mathrm{~b}$. Occidental once again stands out by being able to increase the annual average net cash from operating activities from USD 6.6 billion (in the first period) to USD 10.5 billion (in the second period) (Figure 7). This result enabled the company to increase the amount allocated for investment activities, which doubled from USD 4.5 billion to USD 9.0 billion from the first to second period (annual averages).

Table 6a. Cash-flow sources (+) and sinks (-) for independents (5-year averages, 2004-2008).

\begin{tabular}{llllll}
\hline Percentage & OXY & EOG & HESS & MRO & Mean \\
\hline CAPEX & -69 & -99 & -98 & -84 & -87 \\
Operations & +108 & +102 & +104 & +115 & +107 \\
Financing & -31 & +1 & -3 & -15 & -12 \\
Exchange & 0 & 0 & 0 & 0 & 0 \\
Cash surplus & 8 & +4 & +3 & +16 & +8 \\
\hline
\end{tabular}


Table 6b. Cash-flow sources (+) and sinks (-) for independents (6-year averages, 2009-2014).

\begin{tabular}{llllll}
\hline Percentage & OXY & EOG & HESS & MRO & Mean \\
\hline CAPEX & -90 & -66 & -66 & -86 & -77 \\
Operations & +105 & +87 & +101 & +113 & +102 \\
Financing & -11 & +16 & -26 & -14 & -9 \\
Exchange & 0 & 0 & 0 & 0 & 0 \\
Cash surplus & +4 & +5 & +9 & +13 & +8 \\
\hline
\end{tabular}

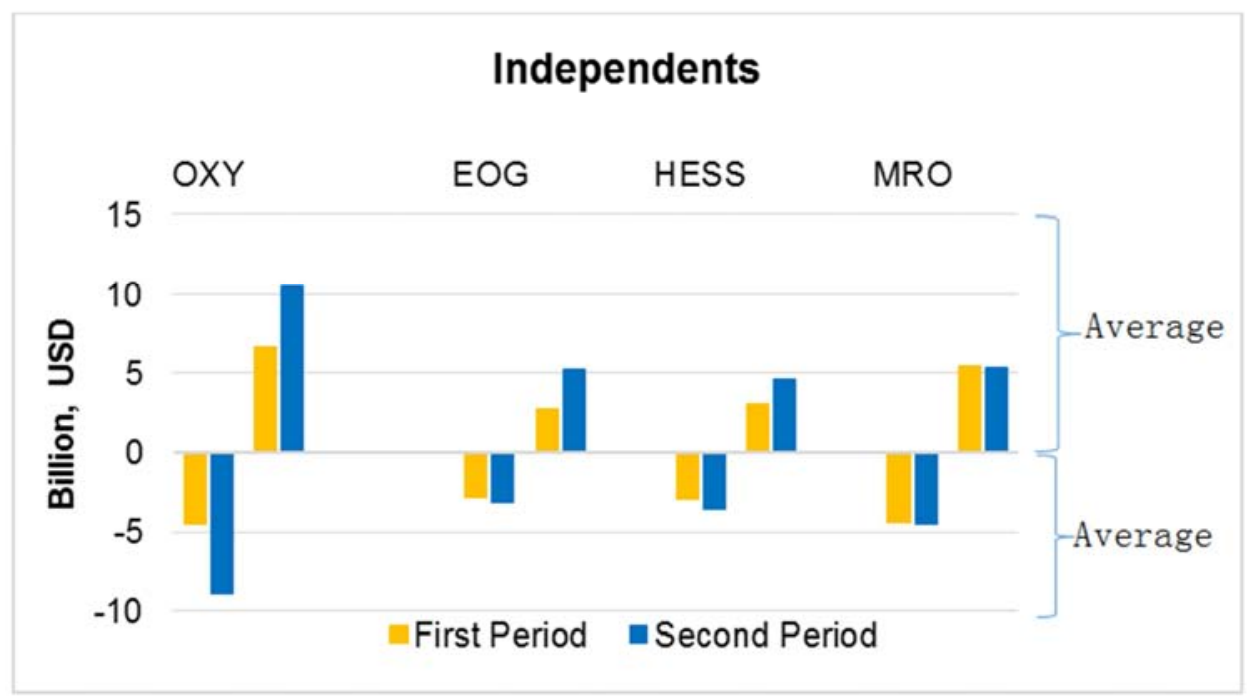

Figure 7. Independents: Average amount in USD billion of cash generated by operations (CFO) and cash spent in CAPEX of new projects.

\subsection{Unconventional Oil and Gas Companies}

This peer group was composed of seven unconventional companies, including three Canadian oil sand producers (Suncor, Imperial, and Canadian Natural Resources) and four American shale oil and gas producers (Southwestern Energy, Range Resources, Chesapeake, and Whiting). Their individual market capitalizations range between USD 5-50 billion (Figure 1).

A) First period (2004-2008). All companies in this peer group relied on supplementary external financing during the first period, except Imperial Oil. The normalized average results over the 5-year period of cash flow data are shown in Table 7a. The peer group funded $15 \%$ of their CAPEX for new projects from external financing (equity financing and debt). Chesapeake depended most on external financing, with CAPEX for new projects for $51 \%$ funded from external financing. In contrast, Imperial Oil in this period presented a cash flow performance nearly as good as that of the major oil companies, spending $69 \%$ of excess earnings in financing activities and with annual cash account surplus of $13 \%$.
B) Second period (2009-2014). The second period was much better for almost all companies in the unconventionals peer group. The normalized average results over the 6-year period of cash flow data are presented in Table $7 \mathrm{~b}$. The average result in cash flow performance showed the companies were able to fully fund CAPEX of new projects from operational net cash. Suncor, followed by Chesapeake and Canadian Natural Resources, had the better cash flow performances in this peer group. After capitalizing all CAPEX of new projects entirely with cash from operating activities, Suncor spent $17 \%$ on financing activities. All companies in this peer group (except Imperial Oil) were able to increase their annual average operational income (Figure 8). Suncor increased operational income annual averages from CAD 3.47 billion (first period) to CAD 7.66 billion (second period). Southwestern Energy more than tripled annual average net cash from operating activities from USD 0.55 billion (first period) to USD 1.77 billion (second period).

Table 7a. Cash-flow sources (+) and sinks (-) for unconventional (5-year averages, 2004-2008).

\begin{tabular}{lllllllll}
\hline & \multicolumn{7}{l}{ Canadian oil sand producers } & \multicolumn{2}{l}{ U.S. shale oil and gas producers } \\
\hline Percentage & Suncor & Imperial & CNQ & SWN & RRC & CHK & Whiting & Mean \\
\hline CAPEX & -91 & -31 & -98 & -96 & -100 & -100 & -100 & -88 \\
Operations & +81 & +113 & +80 & +76 & +54 & +49 & +57 & +73 \\
Financing & +10 & -69 & +18 & +28 & +45 & +54 & +41 & +18 \\
Exchange & 0 & 0 & 0 & 0 & 0 & 0 & 0 & 0 \\
Cash surplus & 0 & +13 & 0 & 8 & 0 & 3 & -2 & +3 \\
\hline
\end{tabular}


Table 7b. Cash-flow sources (+) and sinks (-) for unconventional (6-year averages, 2009-2014).

\begin{tabular}{lllllllll}
\hline & \multicolumn{7}{l}{ Canadian oil sand producers } & \multicolumn{2}{l}{ U.S. shale oil and gas producers } \\
\hline Percentage & Suncor & Imperial & CNQ & SWN & RRC & CHK & Whiting & Mean \\
\hline CAPEX & -76 & -100 & -89 & -100 & -94 & -72 & -98 & -90 \\
Operations & +103 & +86 & +96 & +77 & +76 & +125 & +81 & +92 \\
Financing & -17 & +4 & -7 & +21 & +18 & -13 & +20 & +4 \\
Exchange & 0 & 0 & 0 & 0 & 0 & 0 & 0 & 0 \\
Cash surplus & +11 & -11 & 0 & -2 & 0 & +38 & +3 & +6 \\
\hline
\end{tabular}

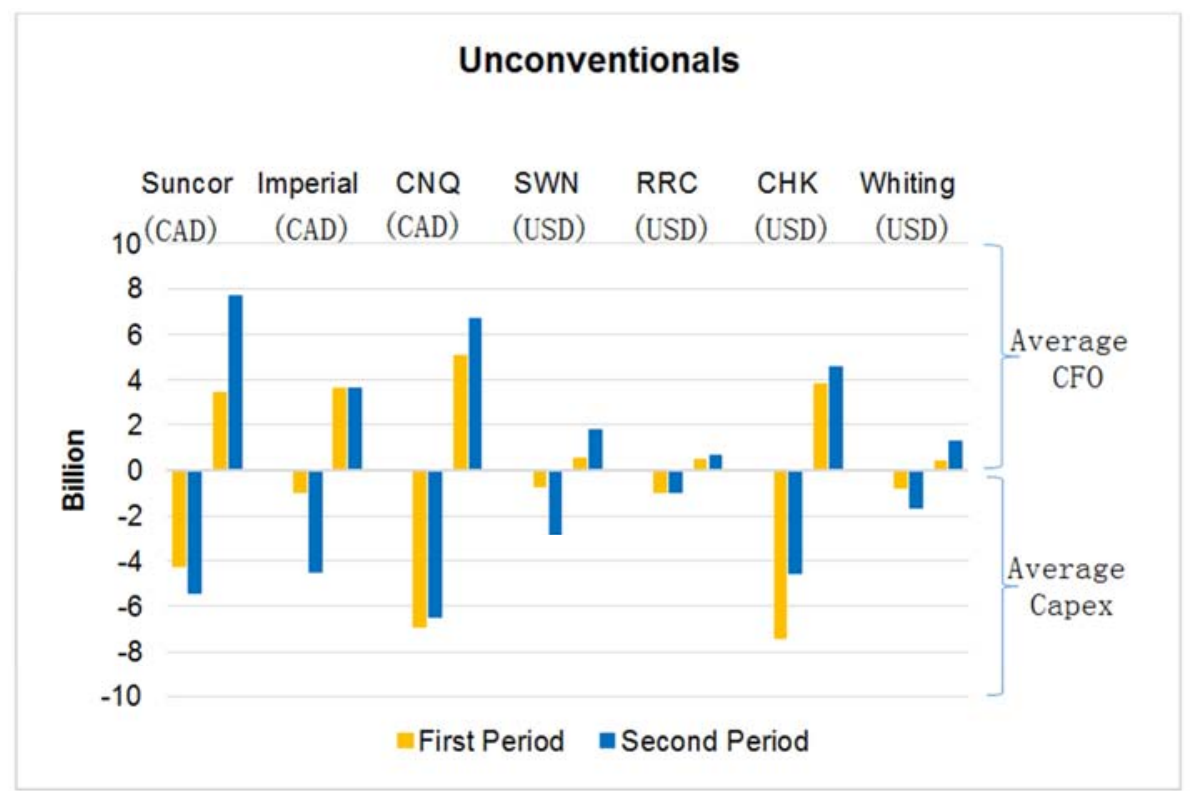

Figure 8. Unconventionals: Average amount of cash generated by operations (CFO) and cash spent in CAPEX of new projects. The currency is specified for each company.

\subsection{Small Cap Oil and Gas Companies}

Five companies comprise this peer group (Table 1, Figure1): three are US-based (SM Energy, Carrizo, and Denbury), one is Canadian (Canadian Oil Sands), and one is European (PremierOil). Their operational incomes typically are not robust enough to cover capital growth projects, so they are usually dependent on external financing for growth. Consequently their cash flows are more vulnerable to uncertain markets.

A) First period (2004-2008). Except for Canadian Oil Sands, all companies in this peer group relied on external financing. They borrowed $6 \%$ to supplement cash from operating income to fund new project CAPEX. Table 8a presents the real averages from the small caps peer group over the 5-year period. In contrast, Canadian Oil Sands was able to fully fund CAPEX projects exclusively with cash from operating activities. Carrizo was most dependent on external financing. Their CAPEX for new projects was $63 \%$ funded from external financing.

B) Second period (2009-2014). The normalized average results over the 6-year period of cash flow performance are presented in Table $8 \mathrm{~b}$. The need for external financing in the second period remained the same as in the first period. However, all the companies increased the annual average amount allocated to investment activities, and that was supported by an increase in operating income over the 6-year performance period (Figure 9). Carrizo for example, increased the annual average amount of investment activities from USD 227 million (first period) to USD 427 million (second period). This was partially funded by its increase in operating income from USD 76 million (first period) to USD 250 million (second period), and supplemented with cash raised in financing activities.

Table 8a. Cash-flow sources (+) and sinks (-) for oil small caps (5-year averages, 2004-2008).

\begin{tabular}{lllllll}
\hline Percentage & COS & SM & Carrizo & Denbury & Premier & Mean \\
\hline CAPEX & -59 & -96 & -100 & -92 & -80 & -85 \\
Operations & +99 & +87 & +37 & +81 & +90 & +79 \\
Financing & -33 & +8 & +65 & +15 & +2 & +11 \\
Exchange & 0 & 0 & 0 & 0 & 0 & 0 \\
Cash surplus & +7 & -1 & +2 & +5 & +12 & +5 \\
\hline
\end{tabular}


Table 8b. Cash-flow sources (+) and sinks (-) for oil small caps (6-year averages, 2009-2014).

\begin{tabular}{lllllll}
\hline Percentage & COS & SM & Carrizo & Denbury & Premier & Mean \\
\hline CAPEX & -69 & -92 & -100 & -92 & -100 & -91 \\
Operations & +108 & +85 & +61 & +101 & +70 & +85 \\
Financing & -40 & +10 & +43 & 0 & +31 & +9 \\
Exchange & 0 & 0 & 0 & 0 & 0 & 0 \\
Cash surplus & -1 & +3 & +4 & +9 & +1 & +3 \\
\hline
\end{tabular}

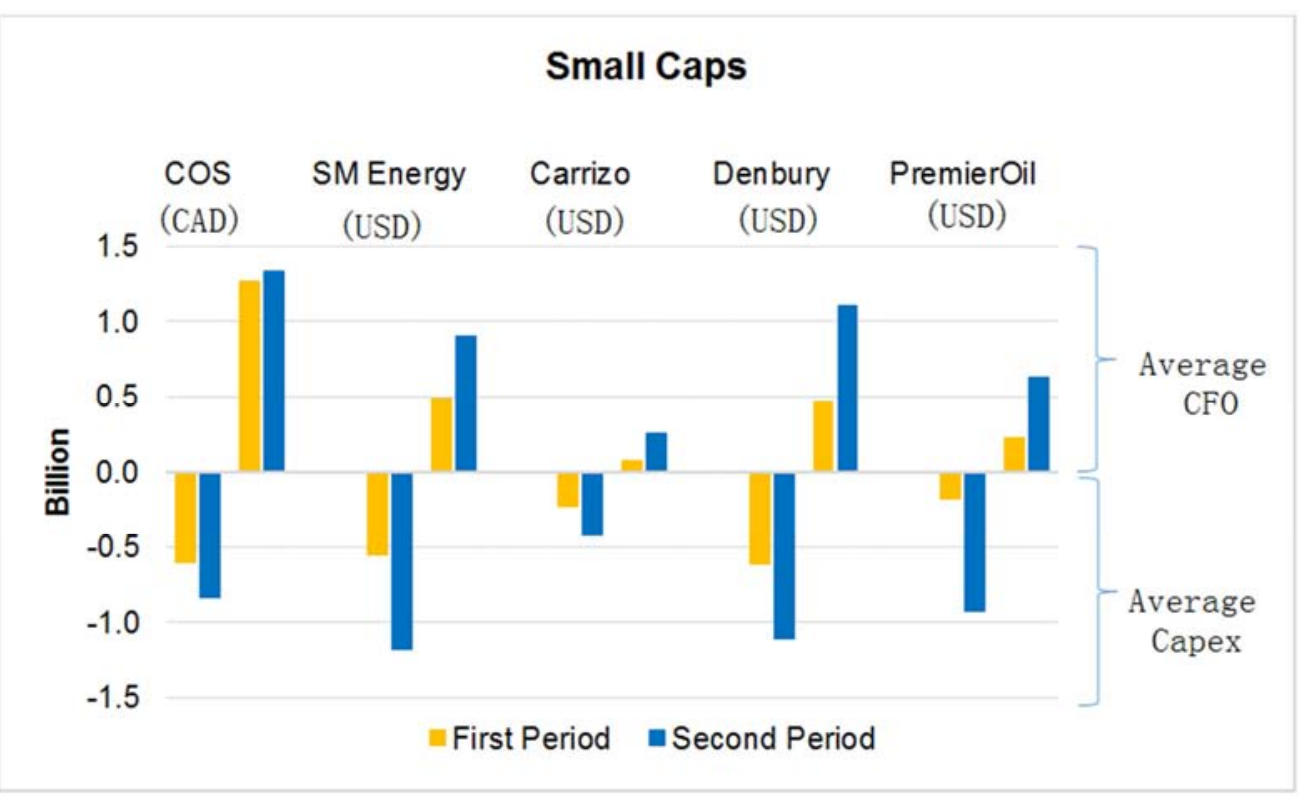

Figure 9. Small Caps: Average amount of cash generated by operations (CFO) and cash spent in CAPEX of new projects. The currency is specified for each company.

\subsection{Junior Oil and Gas Companies}

The juniors peer group (Table 1, Figure1) includes three American companies (Rex Energy, Goodrich Petroleum, and Swift Energy) and one European company (Petroceltic). Their market capitalizations are less than USD 0.5 billion (Figure 1). They traditionally have a huge need to raise external money to fund growth because their operating incomes are not sufficient. They are junk-bond-rated (Table 3) which makes it difficult for them to locate financing with affordable interest rates (see rate comparison in [14]).

A) First period (2004-2008). The normalized average results over the 5-year period of cash flow data are shown in Table 9a. The peer group funded $82 \%$ of their CAPEX for new projects from external financing (equity financing and debt). Petroceltic exemplified the extreme, with normalized real average data showing $175 \%$ of CAPEX of new projects was funded with cash from external financing. Total net cash from operating activities for the 5-year period (2004-2008) was negative USD (-2.8) million, but cash spent on investing activities was USD 79.5 million. The cash raised from financing activities was USD 124 million, and the annual cash account surplus was USD 43 million.

B) Second period (2009-2014). The juniors realized better cash flow in the second period as compared to the first period. The normalized average results over the 6-year period of cash flow data are shown in Table 9b. They exhibit a considerable reduction in dependence on external financing (from $82 \%$ to $42 \%$ financing for CAPEX projects). This improvement is due to an increase in net cash from operating activities. Except for Swift Energy, all companies in this peer group achieved a meaningful improvement in operating income (Figure 10). For example, Rex Energy improved average net cash from operations to USD 73 million in the second period, as compared to USD 16 million in the first period.

Table 9a. Cash-flow sources (+) and sinks (-) for juniors (5-year averages, 2004-2008).

\begin{tabular}{|c|c|c|c|c|c|}
\hline Percentage & Petroceltic & $\operatorname{Rex}$ & Goodrich & Swift & Mean \\
\hline CAPEX & -192 & -100 & -100 & -100 & -123 \\
\hline Operations & -17 & +39 & +48 & +94 & +41 \\
\hline Financing & +353 & +66 & +69 & +9 & +124 \\
\hline Exchange & -70 & 0 & 0 & 0 & -18 \\
\hline Cash surplus & +166 & +4 & +17 & +2 & +47 \\
\hline
\end{tabular}


Table 9b. Cash-flow sources (+) and sinks (-) for juniors (6-year averages, 2009-2014).

\begin{tabular}{llllll}
\hline Percentage & Petroceltic & Rex & Goodrich & Swift & Mean \\
\hline CAPEX & -68 & -100 & -99 & -96 & -91 \\
Operations & +26 & +40 & +51 & +79 & +49 \\
Financing & +67 & +64 & +36 & +22 & +47 \\
Exchange & 0 & 0 & 0 & 0 & 0 \\
Cash surplus & -4 & +4 & -11 & +6 & -1 \\
\hline
\end{tabular}

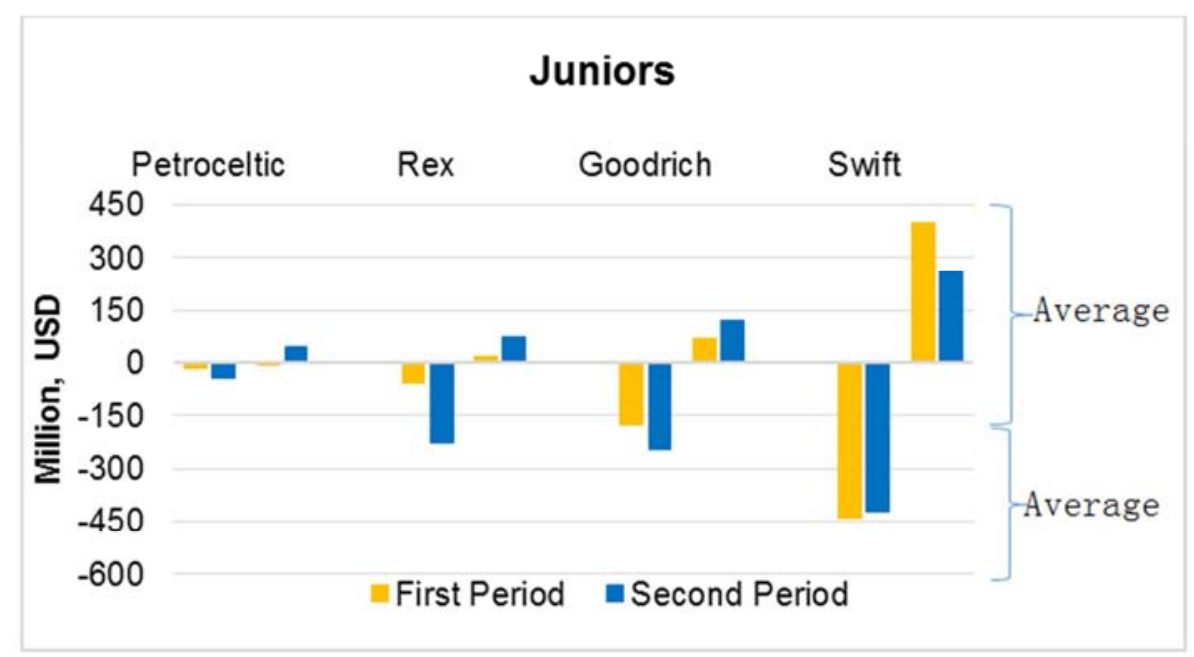

Figure 10. Juniors: Average amount in USD million of cash generated by operations (CFO) and cash spent in CAPEX for new projects.

\section{Trend Analysis of Cash from Operations (CFO) and Spending on Investing Activities (CAPEX)}

The decline in prices of commodities (such as oil and gas) that accompanied the global economic slowdowns (20082009 and 2014-2016) has strained the financial performance of oil and gas companies. Oil companies of all sizes and production types increasingly need to develop strategies to sustain growth and manage risk during fluctuations in the commodities market. This requires continual monitoring and adjustment of investment plans and decision-making processes [24]. The performance period studied here (20042014) has seen an increase in costs for reserve replacement combined with higher uncertainty in oil and gas prices. Our cash flow analysis has revealed a number of clear performance trends, which are further highlighted below.

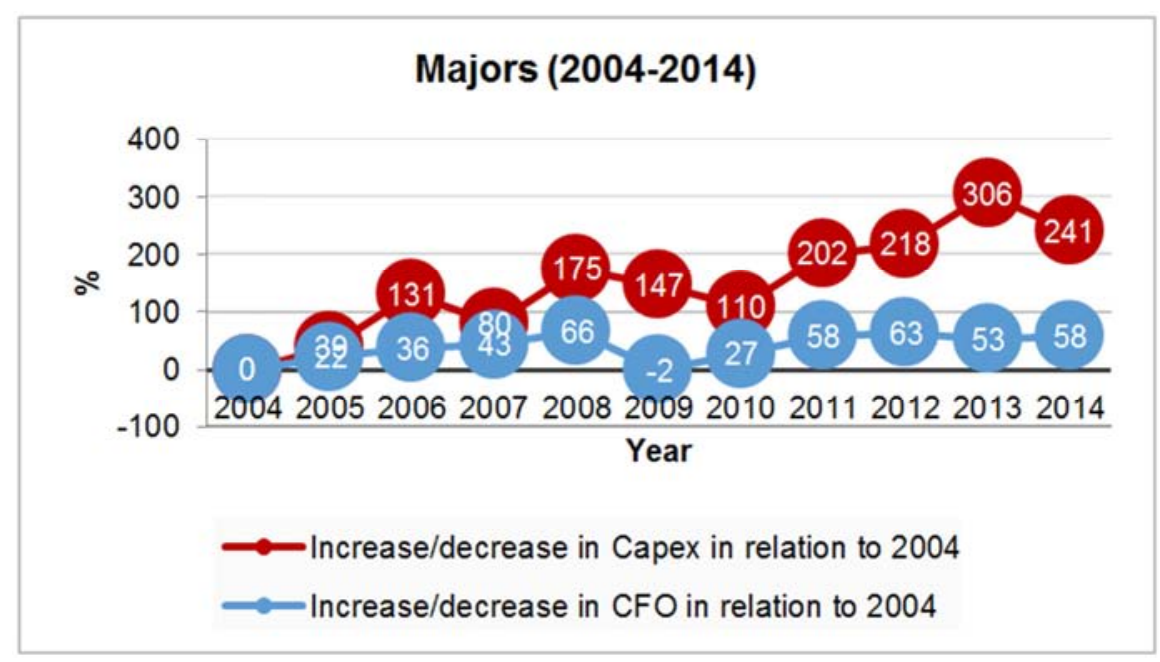

Figure 11. Majors: Change of cash from operations (CFO) and CAPEX starting from 2004 base value. Peer group average percentages of CFO and CAPEX were obtained from the absolute values of CFO and CAPEX of each company by first calculating a percentage change of CFO and CAPEX (increase/decrease from 2005 to 2014) for each company in relation to 2004, which was subsequently averaged.

\subsection{Major Oil and Gas Companies}

Analysis of the sources and uses of cash for the majors peer group demonstrated that there is a growing gap between CFO and CAPEX in the last 10 years, which confirms the 
conclusions of earlier studies [7,8]. Figure 11 presents the change in percentage of CFO and CAPEX starting from the 2004 base value. The widest gap in percentage for that period occurred in 2013, when the net cash from operating activities had increased only $53 \%$ against a $306 \%$ rise of CAPEX spending as compared to 2004. Gaps are expressed as percentages rather than absolute sums to allow easy comparison of trends across peer groups. In addition to allocating investment for new projects, such as prospecting for new reserves and developing new fields, another critical factor for majors is the depletion of their oil fields year after year (approximately 7\% annual decline worldwide) [25]. This means that even to maintain the production level constant at its current level, investment is required to stimulate existing wells.

The major oil companies have increasingly divested underperforming assets in order to concentrate on selective investments that enhance long-term value. The remainder of net income minus retained earnings has been used to buy back shares to support stock prices. For example, ExxonMobil spent USD 47 billion on share repurchases from 2012 to 2014. Similarly, Chevron's board of directors approved in July 2010 an ongoing share repurchase program, which resulted in a total repurchase of 180.9 million shares for USD 20.0 billion.

Another new development for the oil majors was heralded in 2012 by ConocoPhillips' decision to separate all downstream, marketing, midstream and chemical operations into a new company named Phillips 66, in order to focus exclusively on the E\&P business. Demergers are one way of strengthening the core business, divestments are another option. For example, Shell generated USD 15 billion with divestments alone in 2014, which included a public offering of Shell Midstream Partners, shale interests in North America and downstream business in some countries. Likewise, BP has divested assets for about USD 43 billion over the past five years, in order to meet the payment of liabilities and legal costs arising after the Macondo accident in the Gulf of Mexico. After the USD 18.7 billion settlement announced in June 2015 , the company can start its journey to recovery.

Total S.A. executed assets sale programs in 2012-2014, and as a result asset value declined USD 9 billion from USD 239 billion in 2013 to USD 230 billion in 2014. Further asset sales are announced for 2015-2017. Offsetting asset divestments, in 2014 Total S.A. bought a $40 \%$ interest in two licenses in the Gainsborough Trough area of northern England for USD 48 million in order to explore shale gas in the UK.

\subsection{PPP Oil and Gas Companies}

Trend analysis for the PPP oil peer group (Figure 12) shows a better efficiency with increasing CFO and CAPEX as compared to the major peer group. From 2004 to 2006 the PPP oils increased the CFO year after year with a rapid increase in CAPEX. Since 2007 there has been a reversal of that trend; CFO has shrunk for this peer group, and CAPEX has been cut back accordingly. Similar to the major companies, the PPPs also sold off some underperforming assets. For example, Repsol began the divestment of LNG assets in 2013. Meanwhile, Argentina expropriated 51\% equity of YPF SA in 2014, damaging the financial solidity of the company. Targeting growth in exploration and production, Repsol reached an agreement to acquire 100\% share capital of the Canadian company Talisman Energy. Repsol hopes this activity will be the engine for company growth in the coming years. Eni announced plans to sell assets worth USD 8.8 billion in 2015-2018, including shares in subsidiaries Galp Energia SGPS and Snam SpA. Petrobras also embarked on a divestment program and sold BRL 23.4 billion in offshore assets and financial restructuring is underway to ensure optimal monetization of the pre-salt reserves.

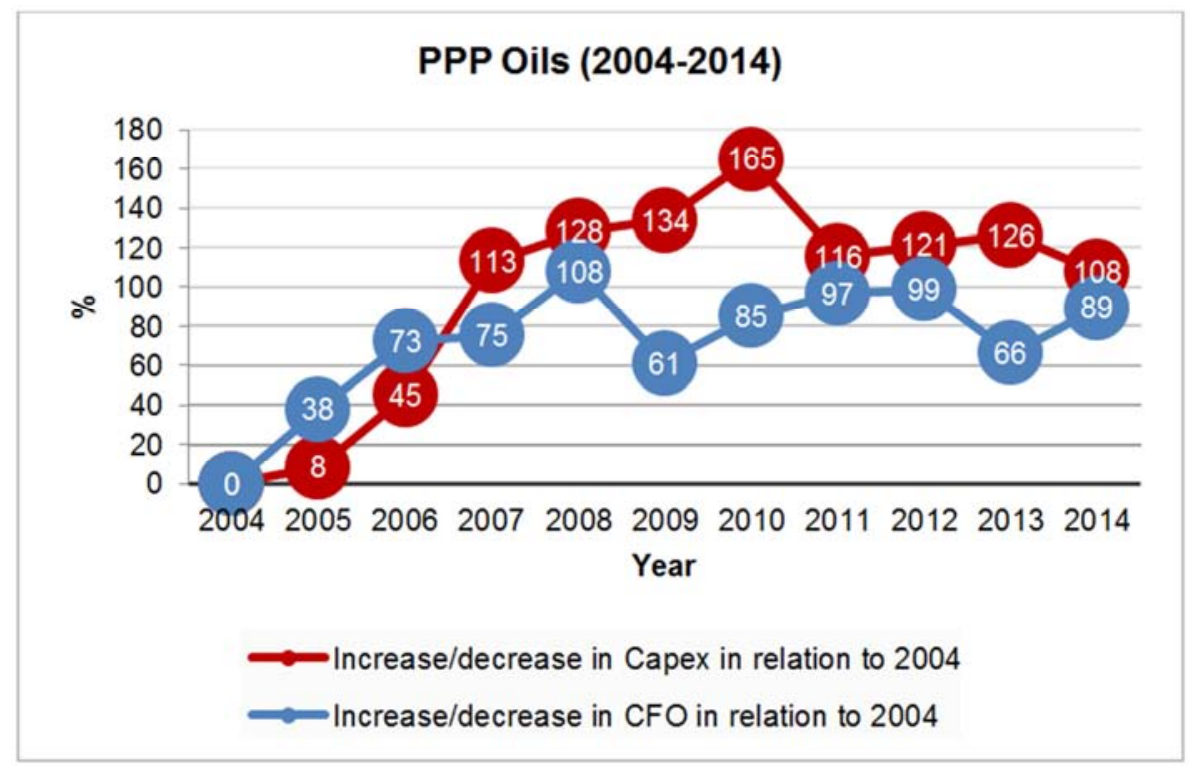

Figure 12. PPP oils: Change of cash from operations (CFO) and CAPEX starting from 2004 base value. 
Statoil continues to outperform all other companies in its peer group. The company made important discoveries in the past five years: in 2010, the Fossekall prospect just north of the Norne oil field in the Norwegian Sea; and in 2011, the large new finds at the Skrugard prospect in the northern Norwegian Sea of the Snøhvit field off Hammerfest, and the huge Aldous Major South discovery on the Norwegian continental shelf. In addition Statoil has invested in enhanced hydrocarbon recovery projects in existing fields and reduced the cost of shale wells.

\subsection{Independent Oil and Gas Companies}

Among the peer groups of bigger companies, the independents show better synchronization between the increase in CAPEX and the increase in CFO until 2012 (Figure 13). However, in 2013 a trend change occurred due to major divestments by a number of companies in the peer group. In our study CAPEX is used in a broader sense, including all investing activities. When asset sales are very large, such as occurred for this peer group in 2013 and 2014, investing activities result in a credit rather than a cost, which explains the decline in CAPEX in those years (Figure 13). For example, Hess announced in 2013 the elimination of downstream businesses, a decision aimed at strengthening their cash flow and allowing them to focus only on E\&P activities. They also divested their trading division (HETCO), retail, as well as E\&P assets in Thailand and Indonesia. In 2011, Marathon also demerged (like Hess) and was divided into Marathon Oil (upstream) and Marathon Petroleum (downstream), in order to strengthen their E\&P businesses. In 2014, Occidental Petroleum Corporation, an international E\&P company with operations in the United States, Middle East region and Latin America, spun-off approximately $80.5 \%$ of the outstanding shares of California Resources. Occidental also sold other assets and ended 2014 with USD 7.8 billion in cash account (which exceeded its long-term debt of USD 6.8 billion).

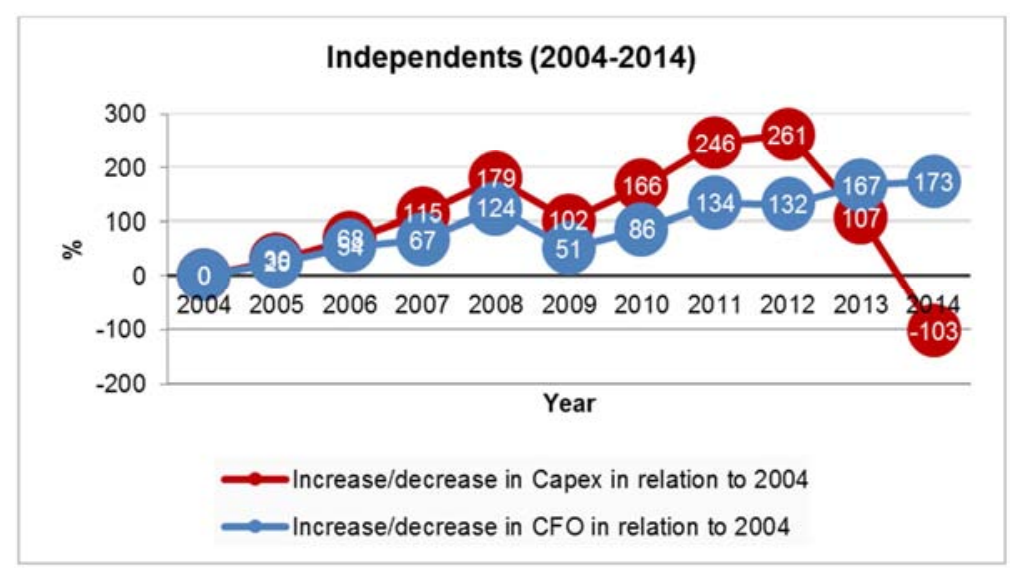

Figure 13. Independents: Change of cash from operations (CFO) and CAPEX starting from 2004 base value.

A comparison of profitability of the four independent companies studied in our peer group is given in Figure 14. EOG is clearly outperforms the others, which is why it has been able to refrain from major asset sales so far. Hess, Marathon, and Occidental all have return on capital employed (ROCE) values falling below the average cost of capital, which may explain the recent divestment policies of these companies. In the past two years, EOG Resources has shown consistent operational cash flow. The company has a large proven reserve base (in the United States, Canada, Trinidad, the United Kingdom and China), significant acreage positions in key North American oil-focused plays and a low cost structure.

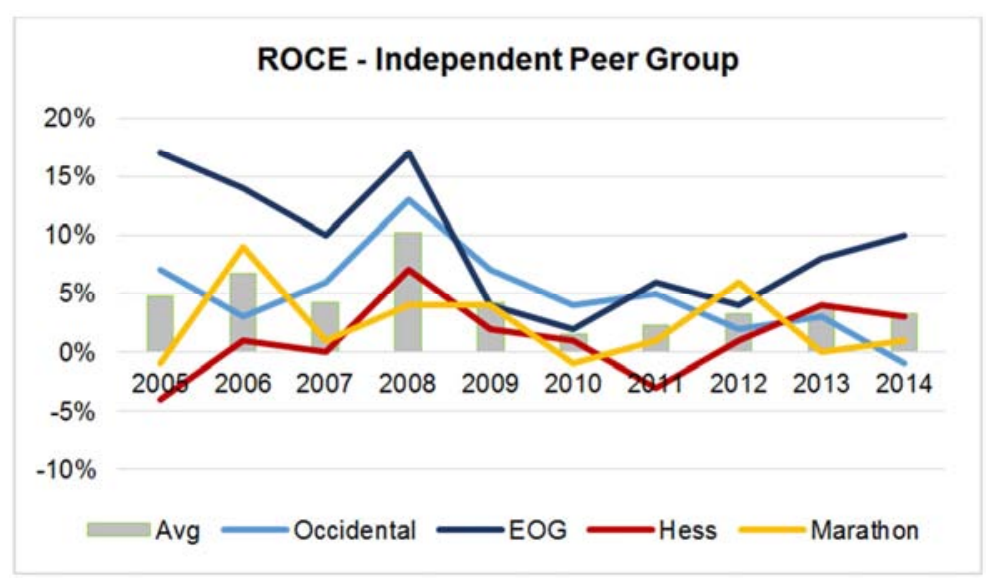

Figure 14. Independents: ROCEs in the period of 2005-2014. 


\subsection{Unconventional Oil and Gas Companies}

A unique feature of the unconventional peer group is that increase in $\mathrm{CFO}$ is consistently larger than growth of CAPEX, except for 2014 (Figure 15). The unconventional peer group indeed has shown great improvement in terms of cash flow in recent years (Figure $4 \mathrm{~b}$ and Table $7 \mathrm{~b}$ ). The trend analysis (Figure 15) shows the unconventional peer group managed to increase its CFO at exceptionally high rates. The companies in this peer group had a 4.5 -fold increase in CFO as compared to 2004 (Figure 15). These companies are on a growth path, which also follows from a market capitalization of USD 24 billion in 2004 ballooning to USD 156 billion in 2014. U.S. shale operators in this peer group grew from USD 7 billion in 2004 to USD 37 billion in 2014; Canadian oil sand operators grew from USD 16 billion to USD119 billion over the same period.

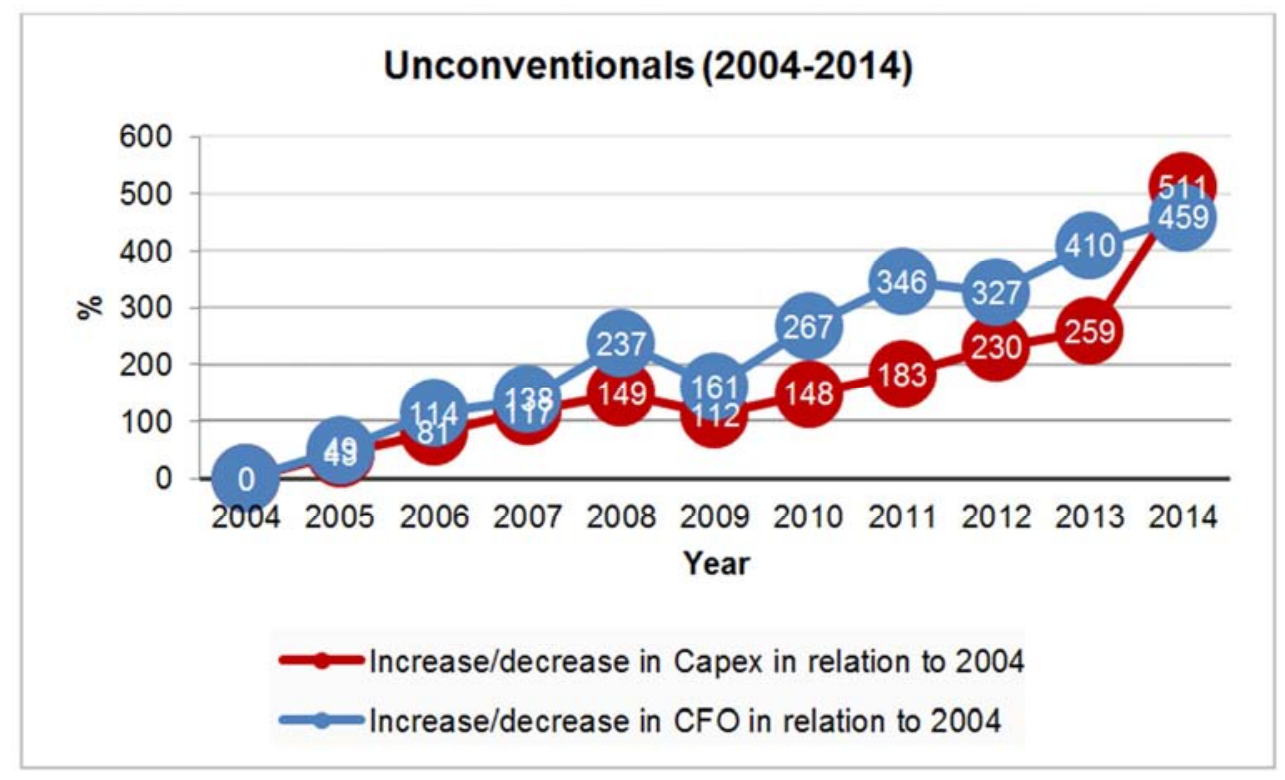

Figure 15. Unconventional: Change of cash from operations (CFO) and CAPEX starting from 2004 base value.

Unconventionals achieved corporate growth in a number of ways. For example, Suncor merged with Petro-Canada in 2009, strengthening the company's cash flow and diversifying its integrated set of assets. The assets of Suncor include oil sands, conventional and offshore production, renewable energy portfolio, refining and marketing under the Petro-Canada brand. To reduce the company's net debt, Suncor sold non-strategic assets for about CAD 3.5 billion in 2010. To increase profit margins, the company has intensified efforts to reduce its oil sands cash operating cost per barrel from CAD $39.05 / \mathrm{bbl}$ in 2011 to CAD $33.80 / \mathrm{bbl}$ in 2014. From 2011 to 2014, Suncor also invested CAD 5.3 billion in a share buyback program.

The growth in market capitalization of U.S. shale operators would have been even greater, were it not for Chesapeake being forced to initiate an asset sales program in 2012 in order to pay down debt and strengthen its financial position. In that year the company sold Permian basin properties valued at approximately USD 6.9 billion and dismantled oilfield service affiliate Chesapeake Oilfield Services. In 2014, further asset divestments occurred in the southern Marcellus and eastern Utica, a transaction which provided the company with approximately USD 5.4 billion. Chesapeake concentrates on the growth of oil and natural gas liquids production, and that has generated better returns than dry gas. Southwestern Energy achieved growth by continued improvement in well performance in the acreage of the company and a large proven reserve base in the Fayetteville and Marcellus shales. In 2014 Southwestern acquired significant assets in West Virginia and southwest Pennsylvania for USD 5.0 billion, which explains the 2014 cumulative peak of $511 \%$ in CAPEX for the peer group. The company has one of the lowest cost structures in the upstream sector and has upgraded efficiency over time. Range Resources operates in the U.S. southwest and Appalachian region and successfully increased average daily production from $196 \mathrm{Mmcfe}$ in 2004 to $1,162 \mathrm{Mmcfe}$ in 2014; proved reserves increased from 1.2 Tcfe in 2004 to 10.3 Tcfe in 2014. Whiting is focused on oil and natural gas liquids with main operations in North Dakota, Colorado, and Texas. Total assets of the company increased from USD 1.1 billion in 2004 to USD 14 billion in 2014; proved reserves increased from 7.9 MMboe in 2004 to 780.3 MMboe in 2014.

\subsection{Small Cap Oil and Gas Companies}

Analysis of the sources and uses of cash for the small caps peer group indicates there is an increase in CAPEX and also an increase in CFO as a result of the CAPEX investment (Figure 16). The small caps peer group accumulates a huge increase of $670 \%$ in CFO in 2014 in comparison to 2014. Such large percentages typically occur for smaller companies when absolute monetary sums are initially small. 


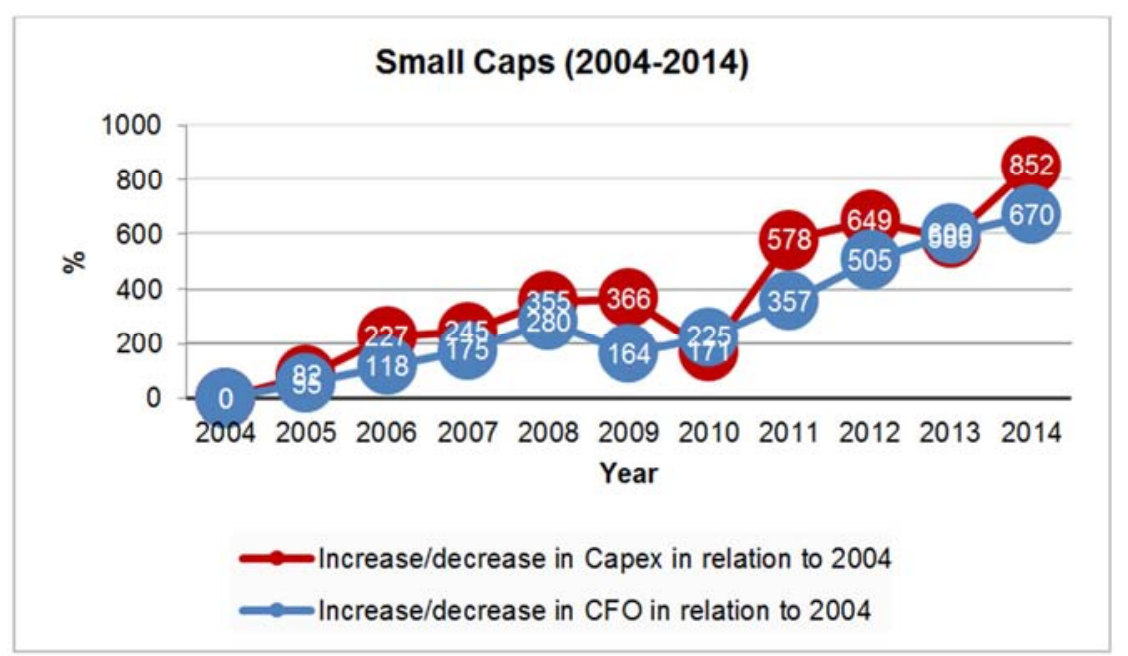

Figure 16. Small Caps: Change of cash from operations (CFO) and CAPEX starting from 2004 base value.

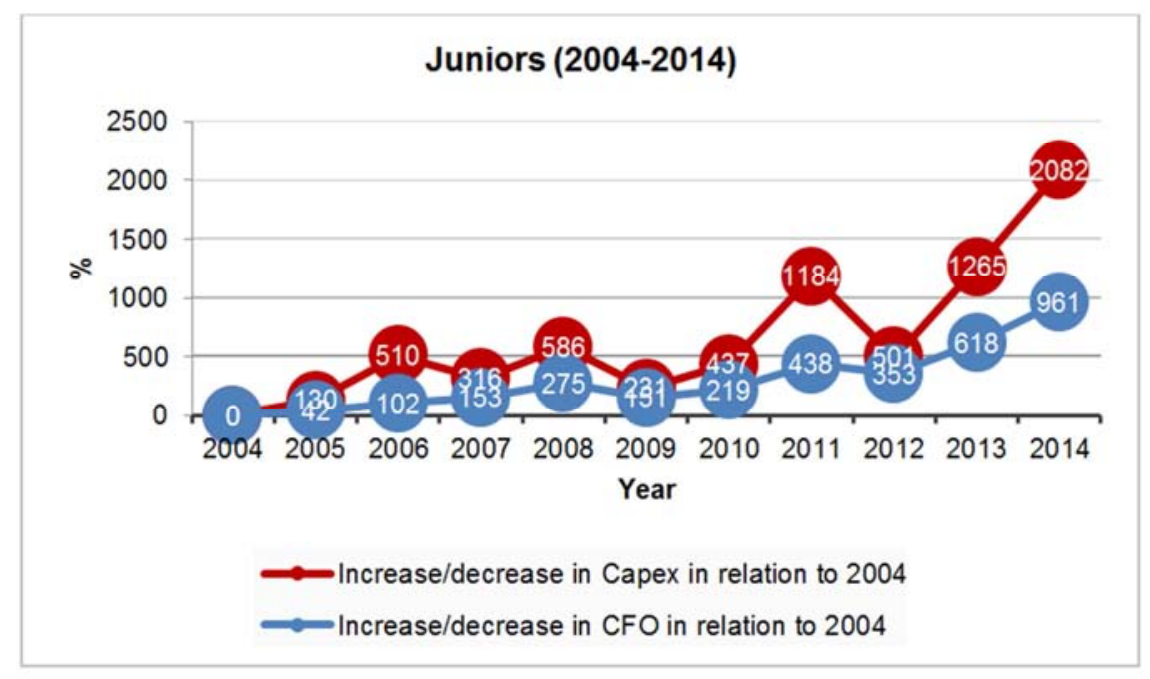

Figure 17. Juniors: Change of cash from operations (CFO) and CAPEX starting from 2004 base value.

In 2011 SM Energy has assets concentrated in the Eagle Ford shale, Bakken/Three Forks shale, and Permian basin. During the 2014 downturn, the company reduced investments and sold some non-strategic assets, mostly properties with higher operating costs, to provide liquidity and focus on the developments of key assets. In 2013 the drilling program was focused on liquids-rich projects, which is the highest return option.

Carrizo has its main operations in the Eagle Ford shale in South Texas, the Marcellus shale in Pennsylvania, the Utica shale in Ohio and the Niobrara formation in Colorado. In 2010 , predicting a gas price drop trend, the company shifted focus and began changing its portfolio from natural gas to crude oil assets. In 2010, the company's production was $92 \%$ natural gas and NGLs, and only $8 \%$ crude oil. In 2014, the production of crude oil accounted for over $60 \%$. Over the years, Carrizo has made efforts to reduce the net debt-toEBITDA ratio below 3: in 2011 the debt ratio was 4; in 2014 it was 2.3. Canadian Oil Sands presents solid cash flow from operations and has a strategy to pay dividends to shareholders. But as a pure-play oil company without portfolio diversification, its cash flow remains highly sensitive to the volatility of oil prices; dividends to shareholders are correlated with oil prices.

Denbury focuses on developing depleted and mature oil fields through the $\mathrm{CO}_{2}$ tertiary recovery method. Its main tertiary reserves are located in the Rocky Mountains and in the Texas Gulf Coast regions. The company has over the years shown great improvement in terms of cash flow and over the period 2012-2014 it has been able to fully fund CAPEX of new projects exclusively with cash from operations. In response to low oil prices, the amount allocated for investment was reduced and in the meantime, Denbury focuses on operating efficiency and cost reduction. Premier Oil had market capitalization of USD 1.1 billion in 2004, climbed to USD 3.5 billion in 2010 and declined to USD 1.3 billion in June 2015. In July 2015, Premier was part of a successful bid, together with its joint venture partners Talos Energy (operator) and Sierra Oil \& Gas, for shallow water Blocks 2 and 7 in Mexico's energy reform Round 1 bids. Block 2 may hold 341 MMboe and Block 7 about 263 MMBoe, according to the National Hydrocarbons Commission. 


\subsection{Junior Oil and Gas Companies}

Junior oil and gas companies show the greatest cumulative increase of CFO of all six peer groups studied, with an increase of $961 \%$ in 2014 compared to the 2004 base value (Figure 17). However, CAPEX increased even faster than CFO, and this expansion makes these companies very vulnerable to the adverse effects of the current decline in oil prices.

Rex Energy operations are focused on the Appalachian Basin (Marcellus, Utica and Upper Devonian Burkett shale) and the Illinois Basin. The company increased its average daily production from 16,102 Mcfe in 2009 to 154,386 Mcfe in 2014; proven reserves increased from 125.2 Bcfe in 2009 to $1,336.8 \mathrm{Bcfe}$ in 2014. Swift Energy has focused on exploiting activities in unconventional (in the Eagle Ford) and conventional acreage (in Louisiana). Total production was 8.3 MMboe in 2010 and 12.4 MMboe in 2014; reserves grew from 132.8 MMboe in 2010 to 193.8 MMboe in 2014. However, not all juniors in our peer group achieved such growth. Goodrich, which still had market capitalization of USD 1.2 billion in 2008, has dwindled to USD 53.7 million in 2015 , and its debt to equity ratio has risen to 28.35 as of June 2015. When this article went to press both Goodrich Petroleum and Swift Energy had filed for bankruptcy.

\section{Discussion}

\subsection{Unconventional Cash-Flow Trends}

Our study performed a detailed benchmark of corporate performance for six peer groups in the oil and gas business by analyzing cash flow data that reflect how each class of company is financed and able to generate cash flow under normal, "favorable" market conditions and makes adjustments when market conditions deteriorate. One of the major surprises from our cash flow analysis is the realization that unconventional oil and gas producers have achieved remarkable improvements in operational cash flow, in spite of the occurrence of two epochs with unfavorably low oil and gas prices (i.e., during the 2008/2009 financial crisis and $2014 / 2016$ oil price war), as follows. American shale producers in our peer group sample realized the most spectacular improvement in operational cash flow from the first period (2004-2008) to the second period (2009-2014). In the latter period, CAPEX could be fully covered by CFO and only $1 \%$ was funded by raising additional financing as compared to $40 \%$ external financing in the first period (20042008) (right column in Figure 18). Producers of Canadian oil sands in our peer group sample have been among the most effective cash flow engines for the full period (2004-2014; Figure 18, left column) even when broken down in the two periods separated by the great recession. The Canadian oil sands producers performed as strongly as independent oil companies (Figure 4a) and did not need any structural income from financing activities. Instead these companies awarded dividends and could retire long-term debt (left column in Figure 18). We infer that Canadian oil sand producers generate sufficient free cash flow because after the high initial investment for oil sand projects, which are essentially the mining plants, production can occur without the high cost of drilling typical for conventional oil operations.

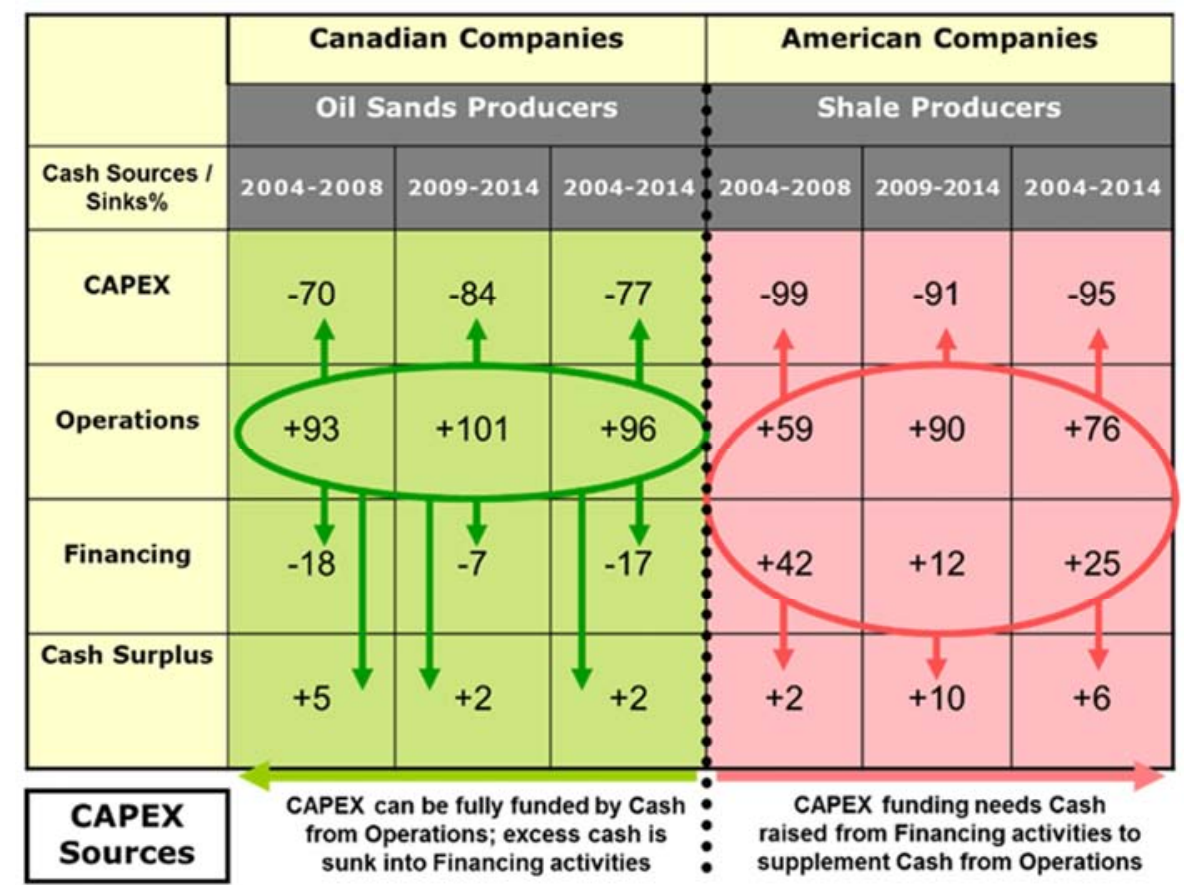

Figure 18. Cash flow sources and sinks for unconventional oil producers. Left column shows Canadian oil sand producers. Right column shows American shale producers. For the period (2009-2014) both peer groups could cover CAPEX largely from CFO, with only minor need for external financing by the shale operators. 
As measured by market capitalization, smaller companies have achieved a higher percentage of growth than the bigger companies in the past 11 years (Figure 19a). The smaller companies in our study successfully developed capital growth projects even while having to raise cash from financing activities to augment their insufficient operating income. Bigger companies resumed growth just after the great recession (2008-2009), but the proportion of growth was at a lower percentage than for the smaller oil and gas companies (Figure 19 a). Examining the outcomes for each peer group (Figure 19b) reveals the extraordinary growth of market capitalization of the unconventional peer group, followed by independent and small cap peer groups. The least overall growth of market capitalization was realized by the oil majors and PPP oils. Juniors had lower market capitalization in 2014 as compared to 2004 (Figure 19b), and bankruptcy ensued for at least two of the companies studied (Goodrich and Swift).

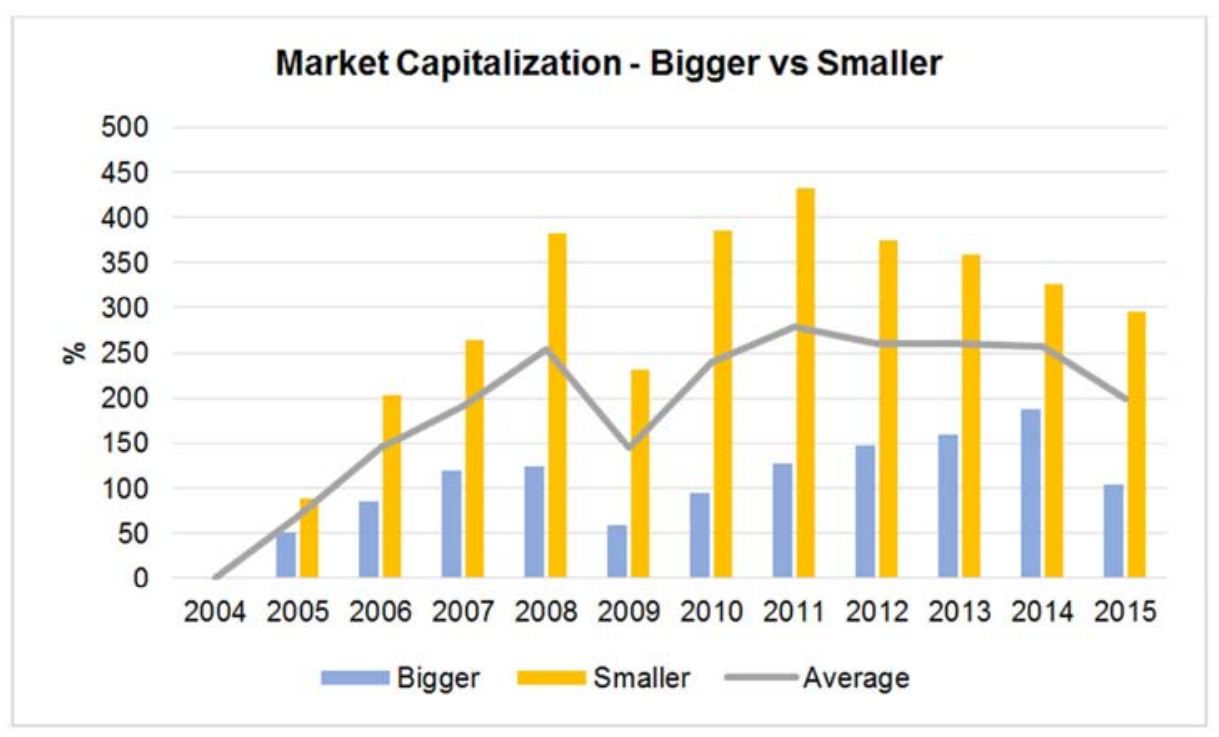

Figure 19a. Evolution of market capitalization of bigger (majors, PPP oils, and independents) and smaller (unconventionals, small caps, and juniors) companies. Note: The market capitalization of Petrobras was not included in this graph.

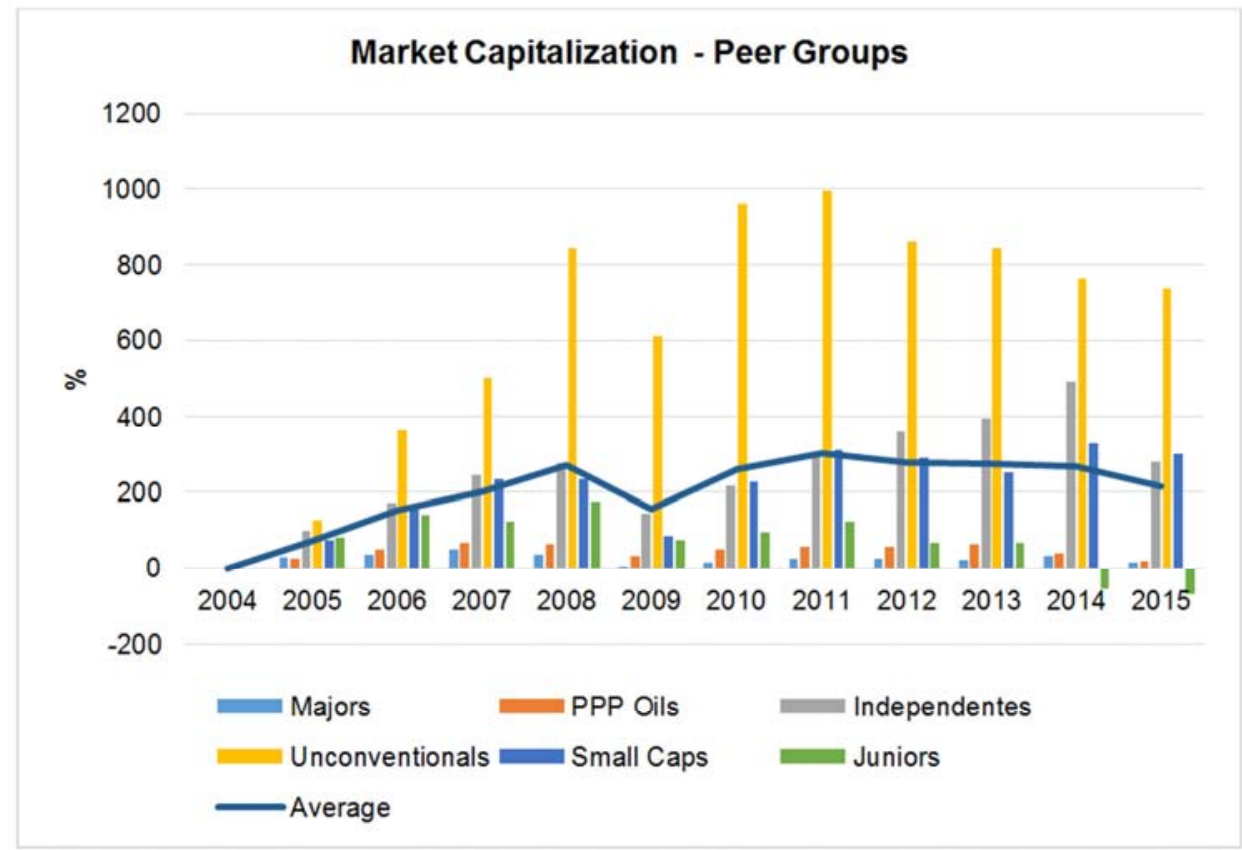

Figure 19b. Market capitalization changes for each of the six peer groups analyzed in our study. Note: The market capitalization of Petrobras was not included in this graph.

\subsection{Recessional Impact on Credit Rating}

Credit ratings and market capitalization tend to positively correlate, especially so for energy companies [14]. When companies ascend from junior oil companies via small-cap to midcap size, and finally large-cap companies, this growth is commonly supported by incremental improvements of the 
companies' credit rating. Table 10 lists an inventory of the 2009 credit ratings for the peer group companies used in both the present and earlier study [14]. A comparison of the December 2009 ratings with those of December 2015 reveals which companies were downgraded or upgraded by the principal credit-rating agencies (e.g., S\&P, Moody's, Fitch, DBRS, RBC) as a succinct measure of oil company performance and credit worthiness over the 6 years epoch $[22$ 26].

The inventory of Table 10 shows the following main trends. The recent decline of commodity prices has drastically eroded the market capitalization of the peer group companies in the last half of 2015 (comparing stocks end June and end December) without any exception. End December 2015, all the oil majors and all PPP peer groups are rated with negative outlooks. In comparison to December 2009, Shell, BP, Total, Eni, Petrobras and Repsol all have lower credit ratings at the end of December 2015. For the independent peer group, ratings have a stable outlook and EOG Resources even received a positive outlook, reflecting the expectation by rating agencies that the company will improve cash from operations to debt to above 60\% in 2017. In comparison to December 2009, only Marathon Oil was downgraded one notch. For the unconventional peer group, Suncor and Canadian Natural Resources have higher credit ratings as of December 2015 as compared December 2009. In contrast, Chesapeake was downgraded from BB in 2009 to $\mathrm{B}$ in December 2015. In the small caps peer group, Denbury was downgraded from BB in 2009 to BB-in 2015 due a 5\% decline in forecasted 2016 production and expectation that CFO to debt will fall below 20\%. SM Energy and Carrizo retained a stable outlook. The Junior peer group typically is highly vulnerable to changes in the business environment. All junior companies studied experienced in the last half of 2015 a greater than $50 \%$ fall in market capitalization (comparing June and December 2015). In December 2015 Moody's downgraded both Goodrich and Swift Energy from Caa1 to Caa3 (with default ratings by S\&P) due to the accelerated erosion in the companies' liquidity position. Both companies teetered on the brink of bankruptcy, and actually went bankrupt (Swift Energy filed 31 December 2015; Goodrich Petroleum filed 15 April 2016).

Table 10. Long term credit ratings of selected companies used in this study.

\begin{tabular}{|c|c|c|c|c|c|c|c|c|}
\hline Company & $\begin{array}{l}\text { S\&P Credit } \\
\text { Rating Dec } \\
2009 \\
\end{array}$ & $\begin{array}{l}\text { S\&P Credit } \\
\text { Rating Dec } \\
2015 \\
\end{array}$ & $\begin{array}{l}\text { CreditWatch/ } \\
\text { Outlook }\end{array}$ & $\begin{array}{l}\text { Moody's Credit } \\
\text { Rating Dec } \\
2009 \\
\end{array}$ & $\begin{array}{l}\text { Moody's Credit } \\
\text { Rating Dec } \\
2015 \\
\end{array}$ & $\begin{array}{l}\text { Market Cap. } \\
\text { (billion USD) } \\
\text { Dec } 2009 \\
\end{array}$ & $\begin{array}{l}\text { Market Cap. } \\
\text { (billion USD) } \\
\text { Jun } 2015 \\
\end{array}$ & $\begin{array}{l}\text { Market Cap. } \\
\text { (billion USD) } \\
\text { Dec } 2015 \\
\end{array}$ \\
\hline \multicolumn{9}{|l|}{ Oil majors } \\
\hline Chevron & $\mathrm{AA}$ & AA & Negative & Aal & Aal & 155.35 & 188.84 & 173.20 \\
\hline Shell & $\mathrm{AA}$ & AA- & Negative & Aal & Aal & 180.00 & 184.79 & 147.60 \\
\hline $\mathrm{BP}$ & $\mathrm{AA}+$ & A & Negative & Aa1 & $\mathrm{A} 2$ & 181.90 & 134.77 & 98.20 \\
\hline $\begin{array}{l}\text { ConocoPhillips } \\
\text { PPP oils }\end{array}$ & A & A & Negative & A2 & $\mathrm{A} 2$ & 75.48 & 78.82 & 60.00 \\
\hline Eni & AA- & A- & Negative & Aa2 & A3 & 92.53 & 64.56 & 55.60 \\
\hline Statoil & AA- & AA- & Negative & $\mathrm{Aa} 2$ & $\mathrm{Aa} 2$ & 80.61 & 58.32 & 45.60 \\
\hline Petrobras & BBB- & BB & Negative & & $\mathrm{Ba} 3$ & 207.64 & 52.90 & 45.60 \\
\hline $\begin{array}{l}\text { Repsol } \\
\text { Independents }\end{array}$ & $\mathrm{BBB}+$ & BBB- & Negative & Baa1 & $\mathrm{Baa} 2$ & 32.78 & 26.22 & 16.70 \\
\hline Occidental & A & A & Stable & A2 & A2 & 64.24 & 59.32 & 52.90 \\
\hline Hess & $\mathrm{BBB}$ & $\mathrm{BBB}$ & Stable & $\mathrm{Baa} 2$ & Baa2 & 19.75 & 18.68 & 14.50 \\
\hline $\begin{array}{l}\text { Marathon } \\
\text { Unconventionals }\end{array}$ & $\mathrm{BBB}+$ & $\mathrm{BBB}$ & Stable & Baa1 & Baa2 & 14.94 & 17.94 & 9.40 \\
\hline Suncor & $\mathrm{BBB}+$ & A- & Negative & Baal & A3 & 55.67 & 41.66 & 38.50 \\
\hline Imperial Oil Ltd & AAA & AAA & Negative & N/A & N/A & 32.49 & 33.56 & 27.80 \\
\hline $\begin{array}{l}\text { Canadian } \\
\text { Natural }\end{array}$ & $\mathrm{BBB}$ & $\mathrm{BBB}+$ & Stable & $\mathrm{Baa} 2$ & Baal & 36.49 & 33.14 & 24.50 \\
\hline Southwestern & N/A & BBB- & Stable & $\mathrm{Ba} 2$ & Baa3 & 17.48 & 9.64 & 2.60 \\
\hline $\mathrm{RRC}$ & N/A & $\mathrm{BB}+$ & Stable & $\mathrm{Ba} 2$ & Ba1 & 8.36 & 9.37 & 4.10 \\
\hline Chesapeake & BB & B & Negative & $\mathrm{Ba} 3$ & B2 & 18.03 & 8.75 & 3.00 \\
\hline $\begin{array}{l}\text { Whiting } \\
\text { Small caps }\end{array}$ & BB & $\mathrm{BB}$ & Stable & $\mathrm{Ba} 3$ & $\mathrm{Ba} 2$ & 3.79 & 6.77 & 2.10 \\
\hline $\begin{array}{l}\text { Canadian Oil } \\
\text { Sands }\end{array}$ & $\mathrm{BBB}$ & BBB- & Positive & $\mathrm{Baa} 2$ & Baa3 & N/A & 4.17 & 3.00 \\
\hline SM Energy & BB & BB & Stable & N/A & Ba1 & 2.26 & 3.24 & 1.40 \\
\hline $\begin{array}{l}\text { PremierOil } \\
\text { Juniors }\end{array}$ & N/A & N/Ad & & N/A & N/A & 1.70 & 8.45 & 0.38 \\
\hline Petroceltic & N/A & N/A & N/A & N/A & N/A & 0.30 & 0.25 & 0.10 \\
\hline Rex Energy & N/A & B- & Stable & N/A & Caal & 0.48 & 0.28 & 0.06 \\
\hline Goodrich & N/A & SD & N/A & N/A & $\mathrm{Caa} 3$ & 0.97 & 0.15 & 0.02 \\
\hline Swift Energy & $\mathrm{B}+$ & D & N/A & $\mathrm{B} 2$ & $\mathrm{Caa} 3$ & N/A & 0.10 & 0.003 \\
\hline
\end{tabular}




\section{Conclusions}

As long as the transition to sustainable energy unfolds and emission tax penalties are not globally applied in current energy policies, oil and gas resources remain primary energy sources fundamental to the worldwide economy. We analyzed the cash flow statements of 30 oil and gas companies from six different peer groups over the past decade. Our study shows how the various assets of different classes of oil companies are financed and how the placement of each class of oil companies adjusts through periods of downturns. Our study both confirms and nuances the earlier finding of Weijermars $[14,16]$ that under normal business conditions, bigger companies have a competitive advantage over smaller companies due to the former having lower cost of-and easier access to-capital. In addition, the need for external financing is almost negligible for bigger companies when business conditions are favorable, because the cash flow from operations amply covers the capital expenses of new projects, and still leaves enough money in the cash account to award dividends to the shareholders and for retiring any debt. In contrast, smaller companies need to raise external cash to complement cash from operations (even when business conditions are favorable) as the latter sums are commonly too small to finance growth (either by organic growth of reserves or acquisition of proven acreage).

When the business climate deteriorates, the competitive disadvantage of young growth companies intensifies. Such companies commonly have a high debt burden and therefore cannot sustain any extended period with suppressed oil and gas prices because investors under such circumstances may find the risk of default outweighing the lure of quick capital gains. When debt-gearing is already high and access to additional financing dries up, forced asset sales and bankruptcies may follow. For example, the steep oil price plunge of late 2014 that persisted through 2016 has resulted in the bankruptcy filing (including Chapter 11 filings) for 77 North American E\&P companies in the period from January 2015 thru May 2016, involving a total of $\$ 51.9$ billion debt [27]. Separately, 61 oilfield service companies filed for bankruptcy in 2015 thru April 2016 with an aggregate debt administered of $\$ 9$ billion [28].

Our research may serve as a timely summary of the different strategies and tactical responses that have been used by petroleum companies over the 11-year study period (2004-2014) and how their operational activities and tactical responses to changes in the business environment have impacted cash flow outcomes. We also highlighted the rising trend in CAPEX and lagging cash flow growth. Looking forward based on our cash flow analysis, we propose the following speculative scenario. Given the spectacular improvement in operational cash flow of the unconventional producers (American shale and Canadian oil sand operators) such growth is likely to resume for surviving and successor companies (in spite of any bankruptcies) as soon as oil prices recover. On the other hand the oil majors showed a dramatic increase in CAPEX relative to CFO, which decreased the operational cash flow for some. If this trend continues, oil majors will increasingly have difficulties finding profitable projects of the asset size they have traditionally developed. Acquisition of the most resilient unconventional operators by the oil majors seems inevitable.

\section{Acknowledgements}

Maria do Socorro Cirilo Agostinho was a participant in the Brazil Scientific Mobility Program (BSMP) sponsored by the Coordination for the Improvement of Higher Education Personnel scholarship (CAPES), Brazil. Terri Smith is thanked for her constructive editing. Anita Bocardo helped with proof reading.

\section{References}

[1] Weijermars, R., Bahn, O., Capros, P., Das, S. R., Griffiths, S., Lund, H., Rogner, H.-H., Taylor, P., Wei, Y.-M., Liao, H. and Shi, X., 2012. Energy Strategy Research: Charter and Perspectives of an emerging discipline. Energy Strategy Reviews, vol. 1, p. 135-137.

[2] GEA, 2012: Global Energy Assessment-Toward a Sustainable Future. International Institute for Applied Systems Analysis, Vienna, Austria and Cambridge University Press, Cambridge, UK and New York, NY, USA.

[3] Murray, J. and King, D. 2012. Climate policy: Oil's tipping point has passed. Nature 481 (7382): 433-435. http://dx.doi.org/10.1038/481433a.

[4] IEA, 2016. World Energy Outlook. http://www.worldenergyoutlook.org/.

[5] Weijermars, R. 2011. Can we close Earth's Sustainability Gap? Renewable \& Sustainable Energy Reviews, Vol. 15, p. 4,6674,672 .

[6] C. A. Dahl, International Energy Markets: Understanding Pricing. Policies and Profits, PennWell Corporation, Tulsa, Oklahoma, 2004.

[7] J. Barron, As cash flow flattens, major energy companies increase debt, sell assets. U. S. Energy Information Administration, Independent Statistics and Analysis, 2014. http://www.eia.gov/todayinenergy/detail.cfm?id=17311 (accessed 01.07.2015).

[8] R. Weijermars, O. Clint, and I. Pyle, 2014. Competing and partnering for resources and profits: Strategic shifts of oil majors during the past quarter of a century. Energy Strategy Reviews, 3, (2014): 72-87. doi: 10.1016/j.esr.2014.05.001

[9] D. Hannesson, Petroleum Economics: Issues and Strategies of Oil and Natural Gas Production, Quorum Books, Westport, Connecticut, 1998.

[10] P. Osmundsen, K. Mohn, M. Emhjellen, and F. Helgeland, Size and Profitability in the International Oil\& Gas Industry. In: The Changing World of Oil: An Analysis of Corporate Change and Adaptation, ed. J. D. Davis, Part 1, Sec. 2, 13-28, Ashgate Publishing Limited. Hampshire, UK, 2006. 
[11] A. C. Inkpen, M. H. Moffett, Global Oil and Gas Industry: Management, Strategy, and Finance, PennWell Corporation, Tulsa, Oklahoma, 2011.

[12] S. Tordo, B. S. Tracy, and N. Arfa, National oil companies and value creation, World Bank Publications no. 218, VA, USA, 2011, $148 \mathrm{pp}$.

http://siteresources.worldbank.org/INTOGMC/Resources/978 0821388310.pdf (accessed 07.07.2015).

[13] M. A. Mian, Project Economics and Decision Analysis: Deterministic Models (Vol. 1), Pennwell Books, 2011.

[14] R. Weijermars, Credit ratings and cash-flow analysis of oil and gas companies: competitive disadvantage in financing costs for smaller companies in tight capital markets. SPE Economics \& Management, 3 (02), (2011), 54-67. SPE144489. doi: $10.2118 / 144489-P A$.

[15] W. Rodrigues, R. Weijermars, Assessing the impact of two recessions on the oil and gas industry: severity of declines and future outlook. First Break, vol. 34 (1) (2016), 79-85.

[16] R. Weijermars, Bigger is better when it comes to capital markets and oil company liquidity. First Break, 28 (6), (2010), 37-41.

[17] T. Jury, Cash Flow Analysis and Forecasting: The Definitive Guide to Understanding and Using Published Cash Flow Data ( $2^{\text {nd }}$ Edition). Hoboken, John Wiley \& Sons, NJ, USA, 2012.

[18] C. J. Wright, R. A. Gallun, Fundamentals of oil \& gas accounting. PennWell Books, 2008.

[19] J. Bajkowski, 1999. A look at the corporate cash flow statement. American Association of Individual Investors Journal, vol. 21 (June), (1999), 26-29. http://www.aaii.com/journal/article/a-look-at-the-corporatecash-flow-statement (accessed 23.06.2015).

[20] J. Livnat, P. Zarowin, The incremental information content of cash-flow components. Journal of Accounting and Economics 13 (1), (1990) 25-46. doi: 10.1016/0165-4101 (90)90066-D.
[21] Weijermars, R., and Watson, S., 2011. Unconventional Natural Gas Business: TSR Benchmark and Recommendations for Prudent Management of Shareholder Value. SPE Economics \& Management, vol. 3, no. 4 (Oct.), p. 247-261, (SPE paper 154056).

[22] J. Jewell, M. Livingston, A Comparison of Bond Ratings from Moody's S\&P and Fitch IBCA. Financial Markets, Institutions and Instruments 8 (4), (1999), 1-45. doi: 10.1111/1468-0416.00029.

[23] R. Sylla, A Historical Primer on the Business of Credit Rating In Ratings, Rating Agencies and the Global Financial System, ed. R. M. Levich, G. Majnoni, and C. Reinhart, Part 1, Sec. 1, 19-40. The New York University Salomon Series on Financial Markets and Institutions, Kluwer Academic Press, Norwell, Massachusetts, 2002.

[24] K. Lee, S. Ni, and R. A. Ratti, Oil shocks and the macroeconomy: the role of price variability. The Energy Journal, Vol. 16 (4), (1995), 39-56.

[25] Energy Information Administration (IEA). 2008. World Energy Outlook-Oil and Gas Production Prospects. Chapter 10, 221-248.

http://aie.org.au/AIE/Documents/IEA_WEO_2008_Oil_Produ ction_Chapter10.pdf (accessed 02.07.2015).

[26] R. J. Kish, K. M. Hogan, and G. Olson, Does the market perceive a difference in rating agencies? The Quarterly Review of Economics and Finance 39 (3), (1999), 363-377. doi: 10.1016/S1062-9769 (99)00005-8.

[27] Haynes and Boone, 2016a. Oil patch bankruptcy monitor. May 16, 2016.

http://www.haynesboone.com/ /media/files/attorney\%20publi cations/2016/energy_bankruptcy_monitor/oil_patch_bankrupt cy_20160106.ashx.

[28] Haynes and Boone, 2016b. Oilfield services bankruptcy tracker. April 29, 2016.

http://www.haynesboone.com/ /media/files/attorney\%20publi cations/2016/ofstracker.ashx. 